\title{
The Activity-Regulated Cytoskeletal-Associated Protein (Arc/Arg3.1) Is Required for Memory Consolidation of Pavlovian Fear Conditioning in the Lateral Amygdala
}

\author{
Jonathan E. Ploski, ${ }^{1}$ Vicki J. Pierre, ${ }^{1}$ Jason Smucny, ${ }^{1,2}$ Kevin Park, ${ }^{1}$ Melissa S. Monsey, ${ }^{1}$ Kathie A. Overeem, ${ }^{1,3}$ and \\ Glenn E. Schafe ${ }^{1,2}$ \\ ${ }^{1}$ Department of Psychology and ${ }^{2}$ Interdepartmental Neuroscience Program, Yale University, New Haven, Connecticut 06520, and ${ }^{3}$ University of Canterbury, \\ Christchurch 8140, New Zealand
}

\begin{abstract}
The activity-regulated cytoskeletal-associated protein (Arc/Arg3.1) is an immediate early gene that has been widely implicated in hippocampal-dependent learning and memory and is believed to play an integral role in synapse-specific plasticity. Here, we examined the role of Arc/Arg3.1 in amygdala-dependent Pavlovian fear conditioning. We first examined the regulation of Arc/Arg3.1 mRNA and protein after fear conditioning and LTP-inducing stimulation of thalamic inputs to the lateral amygdala (LA). Quantitative real-time PCR, in situ hybridization, Western blotting and immunohistochemistry revealed a significant upregulation of Arc/Arg3.1 mRNA and protein in the LA relative to controls. In behavioral experiments, intra-LA infusion of an Arc/Arg3.1 antisense oligodeoxynucleotide (ODN) was observed to be anatomically restricted to the LA, taken up by LA cells, and to promote significant knockdown of Arc/Arg3.1 protein. Rats given intra-LA infusions of multiple doses of the Arc/Arg3.1 ODN showed an impairment of LTM (tested 24 later), but no deficit in STM (tested $3 \mathrm{~h}$ later) relative to controls infused with scrambled ODN. Finally, to determine whether upregulation of Arc/Arg3.1 occurs downstream of ERK/MAPK activation, we examined Arc/Arg3.1 expression in rats given intra-LA infusion of the MEK inhibitor U0126. Relative to vehicle controls, infusion of U0126 impaired training-induced increases in Arc/Arg3.1 expression. These findings suggest that Arc/Arg3.1 expression in the amygdala is required for fear memory consolidation, and further suggest that Arc/Arg3.1 regulation in the LA is downstream of the ERK/MAPK signaling pathway.
\end{abstract}

Key words: Arc; LTP; amygdala; fear conditioning; ERK; classical conditioning

\section{Introduction}

Fear conditioning is a type of associative learning in which an animal comes to exhibit a defensive response to a neutral conditioned stimulus (CS) after repeated pairings with an aversive unconditioned stimulus (US). In the laboratory, this is typically accomplished by pairing a light or tone (CS) with a brief electric shock to the feet (US).

The use of fear conditioning for the study of memory presents several advantages to the investigator: it is quickly acquired, it is long lasting, and it is common to a number of species (LeDoux, 2000). As a result, fear conditioning has been readily characterized at the behavioral, neurophysiological, and pharmacological levels (LeDoux, 2000; Blair et al., 2001; Maren, 2001). Collectively, findings suggest that fear conditioning involves integration of CS and US inputs in the lateral nucleus of the amygdala (LA), where alterations in synaptic transmission encode key aspects of the learning (Schafe et al., 2001). Lesions of the LA inter-

\footnotetext{
Received April 16, 2008; revised Sept. 12, 2008; accepted 0ct. 9, 2008.

This work was supported by National Institutes of Health Grant MH 073949 and by Yale University. We thank Dr. John Guzowski for helpful discussions about this work.

Correspondence should be addressed to Dr. Glenn E. Schafe, Department of Psychology, Yale University, 2 Hillhouse Avenue, Box 208205, New Haven, CT 06520. E-mail: glenn.schafe@yale.edu. DOI:10.1523/JNEUROSCI.1662-08.2008

Copyright $\odot 2008$ Society for Neuroscience $\quad 0270-6474 / 08 / 2812383-13 \$ 15.00 / 0$
}

fere with fear conditioning (LeDoux et al., 1990; Nader et al., 2001), and fear conditioning induces neural plasticity in the LA (Quirk et al., 1995; Rogan et al., 1997; Goosens and Maren, 2004; Schafe et al., 2005). Furthermore, recent reports have indicated that fear conditioning requires the activation of several membrane-bound receptors in the LA, including the NMDA receptor (NMDAR) and the L-type voltage-gated calcium channel (L-VGCC) (Miserendino et al., 1990; Rodrigues et al., 2001; Bauer et al., 2002), the activation of growth factor receptors (Rattiner et al., 2004), protein kinase signaling pathways (CaMKII, PKA, ERK/MAPK, PI-3 kinase) (Schafe et al., 2000; Schafe and LeDoux, 2000; Lin et al., 2001; Rodrigues et al., 2004b), and the transcription factor CREB (Josselyn et al., 2001). However, whereas much has been learned about the intracellular signaling mechanisms that contribute to fear learning and memory formation, little remains known about the downstream genes that underlie long-term storage of fear memories.

One candidate downstream target of cAMP-ERK-CREB signaling during fear conditioning is the activity-regulated cytoskeletal-associated protein (Arc/Arg3.1). Arc/Arg3.1 is a unique immediate early gene (IEG) that can be induced by neural activity and specifically trafficked and localized to recently potentiated synapses where it can interact with structural proteins as well as proteins critical to synaptic plasticity (Steward et al., 1998; 
Steward and Worley, 2001a). Importantly, Arc/Arg3.1 has been shown to be upregulated at synaptic sites during conditions that induce long-term synaptic plasticity (Steward et al., 1998; Moga et al., 2004). In the hippocampus, for example, spatial learning and memory induces Arc/Arg3.1 mRNA and protein at CA1 synapses (Montag-Sallaz and Montag, 2003), and antisense inhibition of Arc/Arg3.1 in the hippocampus impairs long-term memory consolidation and synaptic plasticity in the dentate gyrus (Guzowski et al., 2000). Thus, it is thought that Arc/Arg3.1 is critical for synapse-specific plasticity and may help explain how transcription of genes in the nucleus leads to long-lasting alterations at far away synaptic sites (Steward and Worley, 2002).

Although involvement of Arc/Arg3.1 has been extensively documented in hippocampal-dependent memory systems, less is known about its role in other types of learning and memory. In this study, we have examined the role of Arc/Arg3.1 in memory consolidation of amygdala-dependent Pavlovian fear conditioning. We first show that Arc/Arg3.1 mRNA and protein is upregulated in the LA in an associative manner after fear conditioning and LTP-inducing stimulation of the LA. We next show that antisense inhibition of Arc/Arg3.1 translation in the LA impairs fear memory consolidation. Finally, we show that fear conditioning-induced upregulation of Arc/Arg3.1 in the LA requires ERK/MAPK activation.

\section{Materials and Methods}

Subjects. Adult male Sprague Dawley rats (Hilltop Labs) were housed individually in plastic cages and maintained on a $12 \mathrm{~h}$ light/dark cycle. Food and water were provided ad libitum throughout the experiment.

Quantitative real-time PCR. Rats were habituated to handling for 2-4 $\mathrm{d}$ before training. "Paired" rats received three conditioning trials consisting of a $20 \mathrm{~s}, 5 \mathrm{kHz}, 75 \mathrm{~dB}$ tone that coterminated with a $1 \mathrm{~s}, 0.5 \mathrm{~mA}$ foot shock. The intertrial interval (ITI) was, on average, $120 \mathrm{~s}$, and the total training time lasted $9 \mathrm{~min}$. Thirty min after training, rats were deeply anesthetized with $\mathrm{CO}_{2}$ and decapitated. "Immediate Shock" control rats were placed in the conditioning chamber and immediately given three $0.5 \mathrm{~mA}$ foot shocks, and were killed $30 \mathrm{~min}$ later. This procedure allows the experimenter to control for shock-induced changes in gene expression in the absence of a context-shock association (Fanselow, 1980). "Tone Alone" rats were placed in the conditioning chamber and exposed to three tones $(20 \mathrm{~s}, 5 \mathrm{kHz}, 75 \mathrm{~dB})$ without receiving shocks. "Naive" control rats were handled and killed without exposure to the box. Immediately after removal, brains were frozen and stored at $-80^{\circ} \mathrm{C}$ until processed. For time course gene expression experiments, rats were killed either 30,90 or 180 min after fear conditioning.

Fresh frozen rat brains were mounted on a sliding freezing microtome and tissue was removed to approximately -3.6 Bregma. The coronal plane was brushed with RNA Later (Ambion) to prevent RNA degradation and to provide rigidity to the tissue slice during dissection. A 480$\mu \mathrm{m}$-thick section was taken (between approximately -3.6 and approximately -3.1 Bregma) and placed in a glass dish with RNA Later. The LA was selectively microdissected using an X-ACTO knife. The dissection was performed on top of a light box to illuminate the amygdala and surrounding structures allowing for accurate microdissection of the LA. The microdissected LA was immediately placed in ice-cold Microfuge tubes, frozen on dry ice, and placed at $-80^{\circ} \mathrm{C}$ until RNA isolation. Samples were homogenized in the Microfuge tube with $800 \mu \mathrm{l}$ of TRIzol Reagent (Invitrogen) with a plastic pestle. RNA isolation was performed according to the manufacturer's instructions. To enhance precipitation, $10 \mu \mathrm{g}$ of RNase-free glycogen (Invitrogen) was added. The isolated total RNA was DNase treated in a $100 \mu$ l reaction with 6.8 Krunitz Units of DNase I (Qiagen) for $10 \mathrm{~min}$ at room temperature followed by total RNA purification using the RNeasy MinElute Kit (Qiagen). RNA purification was performed according to the manufacturer's instructions.

Quantitative real-time PCR (qRT-PCR) was performed using the $\Delta \Delta$ Ct method as described previously (Ploski et al., 2006) using qRT-
PCR primers for Arc/Arg3.1 (forward primer CCCTGCAGCCCAAGTTCAAG; reverse primer GAAGGCTCAGCTGCCTGCTC). Relative gene concentrations were normalized against GAPDH (forward primer GCATCCTGCACCACCAACTG; reverse primer ACGCCACAGCTTTCCAGAGG). Data for paired, immediate shock, and tone alone animals were normalized to the average value of naive controls, and data were analyzed using ANOVA.

In situ hybridization. For in situ hybridization experiments, Paired, Immediate Shock, and Naive rats were prepared as above. RNA radioactive probes were generated by PCR amplification using gene-specific primers for Arc/Arg3.1 (forward primer GGTGAGGATGGGCAACCAAG; reverse primer atacgactcactatagggaga-TGCTTCTGTGGCAGGTCCAG). The reverse primer included a T7 template sequence (shown in lowercase). Rat hippocampal cDNA was used as the template for PCR, which was performed in a MJ-Mini Gradient Thermal Cycler (Bio-Rad) using the Quantitect Sybr Green PCR kit (Qiagen). The PCR product was purified by ethanol precipitation and was resuspended in TE buffer. One microgram of the $300 \mathrm{bp}$ PCR product was used to produce radiolabeled probe using a T7-based in vitro transcription kit (Megashortscript; Ambion) using $\left[{ }^{35} \mathrm{~S}\right] \mathrm{CTP}(75 \mu \mathrm{Ci})$ and $\left[{ }^{35} \mathrm{~S}\right] \mathrm{ATP}(75 \mu \mathrm{Ci})$. Removal of unincorporated nucleotides after the in vitro transcription reaction was performed using Sepharose spin columns (Roche).

In situ hybridization was performed as described previously (Newton et al., 2003). Briefly, cryostat cut frozen sections (15 $\mu \mathrm{m})$ were slidemounted, and stored at $-80^{\circ} \mathrm{C}$ until further processing. Slide mounted sections were fixed in $3 \%$ paraformaldehyde and ethanol dehydrated. Sections were then air dried for $1-2 \mathrm{~h}$, followed by hybridization with the ${ }^{35} \mathrm{~S}$-radiolabeled antisense probe in a sealed humid chamber at $55^{\circ} \mathrm{C}$ for 14-18 h. Slide mounted sections were then washed, air-dried, and slides were exposed to autoradiographic film (BioMax MR, Kodak) for 2-7 d. Relative gene expression changes were determined using NIH ImageJ (http://rsb.info.nih.gov/ij/). Gene expression intensity was normalized against film background for each section, and averages were determined for at least two sections per slide per rat. Data were analyzed using ANOVA.

Western blotting. For Western blotting experiments, Paired, Immediate Shock, and Naive rats were prepared as above, with the exception that they were killed $2 \mathrm{~h}$ after training or shock exposure. Before decapitation rats were given an overdose of chloral hydrate $(250 \mathrm{mg} / \mathrm{kg}$; i.p.), and brains were frozen at $-80^{\circ} \mathrm{C}$ until processed. Punches containing the LA were obtained with a $1 \mathrm{~mm}$ punch tool (Fine Science Tools) from 400$\mu \mathrm{m}$-thick sections taken on a sliding freezing microtome. Punches were manually dounced in $50 \mu \mathrm{l}$ of ice-cold hypotonic lysis buffer [10 mM Tris- $\mathrm{HCl}, \mathrm{pH}$ 7.5, 1 mм EDTA, $2.5 \mathrm{~mm}$ sodium pyrophosphate, $1 \mathrm{~mm}$ phenylmethylsulfonyl fluoride, $1 \mathrm{~mm} \beta$-glycerophosphate, $1 \%$ Igepal CA-630, $1 \%$ protease inhibitor mixture (Sigma), and $1 \mathrm{~mm}$ sodium orthovanadate]. Protein concentrations were assessed and normalized across homogenates using a Bradford assay. Sample buffer was immediately added to the homogenates, and the samples were boiled for $4 \mathrm{~min}$. Homogenates were electrophoresed on $10 \%$ Tris- $\mathrm{HCl}$ gels and blotted to Immobilon-P (Millipore). Western blots were blocked in TTBS buffer (50 mu Tris- $\mathrm{HCl}, \mathrm{pH} 7.5,150 \mathrm{~mm} \mathrm{NaCl}$, and $0.05 \%$ Tween 20 ) with $5 \%$ dry milk and then incubated with an anti-Arc/Arg3.1 antibody (1:1000; Santa Cruz Biotechnology). Blots were then incubated with anti-rabbit conjugated to horseradish peroxidase (Cell Signaling) and developed using West Dura chemiluminescent substrate (Pierce Laboratories). Western blots were developed in the linear range used for densitometry. Densitometry was conducted using NIH ImageJ software. To control for inconsistencies in loading, optical densities were normalized to either actin or GAPDH proteins. Data for paired and immediate shock animals were normalized to the average value of naive controls, and data were analyzed using ANOVA.

Immunohistochemistry. For immunohistochemical experiments, Paired, Immediate Shock, and Naive rats were treated as in the Western blot experiments. Two hours after training, rats were rapidly and deeply anesthetized with chloral hydrate $(250 \mathrm{mg} / \mathrm{kg}$, i.p. $)$ and perfused through the heart with phosphate buffered saline (PBS), followed by ice-cold $4 \%$ paraformaldehyde in $0.1 \mathrm{~m}$ phosphate buffer $(\mathrm{PB})$. Brains were removed and postfixed in $4 \%$ paraformaldehyde-PB for $12 \mathrm{~h}$ and then cryopro- 
tected in $20 \%$ glycerol- 0.1 м PB for $48-72$ h. Free-floating sections (40 $\mu \mathrm{m})$ containing the amygdala were cut using a sliding microtome. Every sixth section was processed for Arc/Arg3.1 immunoreactivity. After blocking in PBS containing 1\% bovine serum albumin (BSA; Sigma Fraction V, Cat \#A-3059)-0.1\% Triton X-100, slices were incubated overnight at room temperature in anti-Arc/Arg3.1 antibody (mouse monoclonal, 1:500; Santa Cruz Biotechnology) in PBS-1\% BSA-0.1\% Triton $\mathrm{X}-100$. After extensive washes in PBS, tissue sections were visualized using VectaStain $\mathrm{ABC}$ kit (Vector Laboratories) and developed in $\mathrm{DAB}$ peroxidase substrate (Sigma) for $5 \mathrm{~min}$. Sections were mounted on Fisherbrand electrostatic slides and coverslipped.

Sections from comparable anterior-posterior levels were selected for scoring, $\sim 3.2-3.3 \mathrm{~mm}$ posterior to Bregma. At this level, the LA, CE, and basal nuclei are all well represented (see Fig. 1e). Cell counts were taken from at least 3 sections per rat and scored using a defined boundary roughly equivalent to the size of the LA using NIH ImageJ. Because every sixth section through the amygdala was processed for immunohistochemistry, it was not necessary to correct for double-counting. For analysis, cell counts were averaged into a single score for each rat, and data were analyzed using ANOVA.

Electrical stimulation experiments. For LTP stimulation experiments, rats $(300-350 \mathrm{~g})$ were anesthetized with Urethane (2 i.p. injections at 10 min intervals; total of $1.6 \mathrm{mg} / \mathrm{kg}$ ) and placed in a stereotaxic frame. The skull was exposed over the auditory thalamus (medial geniculate nucleus and posterior intralaminar nucleus; MGm/PIN), the dura was retracted, and rats were implanted with a bipolar stimulating electrode into the $\mathrm{MGm} / \mathrm{PIN}$. Coordinates for MGm/PIN were -5.0 anterior-posterior, 2.9 medial-lateral, -6.6 dorsal-ventral. One-half hour after implantation of the stimulating electrode, rats were given LTP-inducing (highfrequency) stimulation (HFS) consisting of three series of thetapatterned $100 \mathrm{~Hz}$ tetani given once a minute at a stimulation intensity of $300 \mu \mathrm{A}, 100 \mu \mathrm{s}$ (Yaniv et al., 2001; Doyère et al., 2003). Low-frequency stimulation controls received the same total number of pulses as rats in the LTP group (300 total pulses over $2 \mathrm{~min}$ ) but at lower frequency (2.5 $\mathrm{Hz}$ ) (Schafe et al., 2008). In all stimulation experiments, current was applied such that it moved from the tip to the tube of the bipolar stimulation electrode. For analysis, we expressed values on the side of the brain ipsilateral to the stimulation as a percentage of those on the contralateral side.

Oligodeoxynucleotide design and preparation. Arc/Arg3.1 and scrambled ODNs (Midland Certified Reagent Company) were designed under guidelines described in the study by Guzowski et al. (2000). The Arc/ Arg3.1 ODN encoded an antisense sequence for the Arc/Arg.31 mRNA sequence near the translation start site (Lyford et al., 1995). The scrambled ODN, which does not show significant homology to any sequences in the GenBank database (Guzowski et al., 2000), served as a control. Both ODNs contained phosphorothioate linkages on the three terminal bases of both the $5^{\prime}$ and $3^{\prime}$ ends and phosphodiester internal bonds, as this nucleotide design is reportedly more stable than unmodified phosphodiester ODNs in vivo and less toxic than fully phosphorotioate ODNs (Guzowski et al. 2000). The following sequences were used (“ " denotes a phosphorothioate linkage): $5^{\prime}-\mathrm{G} \sim \mathrm{T} \sim \mathrm{C} \sim \mathrm{CAGCTCCATCTGCT} \sim \mathrm{C} \sim$

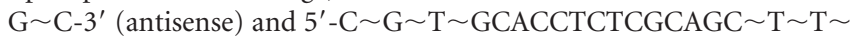
$\mathrm{C}-3^{\prime}$ (scrambled). This antisense sequence has been shown to effectively knock down Arc/Arg3.1 protein expression in the hippocampus and to exhibit a high degree of specificity for Arc/Arg.3.1 relative to other IEGs (Guzowski et al., 2000).

Verification of ODN diffusion and knockdown. To verify diffusion of the Arc/Arg3.1 oligonucleotide in the LA and its effectiveness in knocking down Arc/Arg3.1 protein expression, rats were first infused with a biotinylated Arc/Arg3.1 antisense ODN (Midland Certified Reagent Company). The biotin-Arc-ODN was infused bilaterally at the dose and volume used in the behavioral experiments $(2 \mathrm{nmol} ; 1 \mu \mathrm{l})$, and rats were killed by perfusion either 3 or $6 \mathrm{~h}$ later. Brains were sectioned on a microtome at $40 \mu \mathrm{m}$ as described above, and sections containing the LA were processed using a standard $\mathrm{ABC}-\mathrm{DAB}$ reaction to visualize the extent of the distribution and cellular uptake of the ODN. To verify knockdown, rats were cannulated as described above and given intra-LA infusion of Arc/Arg3.1 antisense ODN on one side of the brain and scrambled
ODN on the contralateral side (both $2 \mathrm{nmol} ; 1 \mu \mathrm{l}$ ). Rats were then killed either 3, 6, or $24 \mathrm{~h}$ later as described for the Western blotting experiments (see above). Punches taken from around the cannula tips were assayed for Arc/Arg3.1 protein using Western blotting. For analysis, levels of Arc/Arg3.1 protein on the antisense-infused side were expressed as a percentage of those on the side infused with scrambled ODN.

Behavioral procedures. Behavioral procedures were conducted as described previously (Schafe et al., 1999; Schafe and LeDoux, 2000). Under a mixture of Ketamine $(100 \mathrm{mg} / \mathrm{kg})$ and Xylazine $(6.0 \mathrm{mg} / \mathrm{kg})$ anesthesia, rats were implanted bilaterally with 23 -gauge stainless steel guide cannulas aimed at the LA. The coordinates for the LA were: $-3.2 \mathrm{~mm}, \pm 5.0$ $\mathrm{mm},-8 \mathrm{~mm}$ relative to Bregma. The guide cannulas were fixed to screws in the skull using a mixture of acrylic and dental cement, and a 28-gauge dummy cannula was inserted into each guide cannula to prevent clogging. Rats were given Buprenex $(0.2 \mathrm{mg} / \mathrm{kg})$ as an analgesic and given at least five $\mathrm{d}$ to recover before experimental procedures. All surgical procedures were conducted in accordance to the National Institutes of Health Guide for the Care and Use of Experimental Animals and were approved by the Yale University Institutional Animal Care and Use Committee. Rats were given at least $5 \mathrm{~d}$ to recover before experimental procedures.

On the day before conditioning, rats were habituated to the conditioning chamber and to dummy cannula removal for a minimum of 10-15 $\mathrm{min}$. The following day, rats were given bilateral intra-LA infusion of either Arc/Arg3.1 antisense or scrambled ODN ( 0.2 or $2 \mathrm{nmol} ; 1 \mu \mathrm{l})$. The infusion cannulas were allowed to remain in the LA for at least 2 min following the infusion to allow ODNs to diffuse throughout the LA.

Six hours after ODN infusions, rats were trained with a single conditioning trial consisting of a $30 \mathrm{~s}, 5 \mathrm{kHz}, 75 \mathrm{~dB}$ tone that coterminated with a $1.0 \mathrm{~s}, 1.5 \mathrm{~mA}$ foot shock. Testing for conditioned fear responses (freezing) was conducted at $3 \mathrm{~h}$ (short-term memory; STM) and $24 \mathrm{~h}$ (longterm memory; LTM) after conditioning. For each test, rats were placed in a distinctive environment consisting of a flat black plastic floor that had been washed with a distinctive peppermint soap (for details, see Schafe et al., 1999) and exposed to five CS tones $(5 \mathrm{kHz}, 75 \mathrm{~dB}, 30 \mathrm{~s})$. Total seconds freezing during the CS presentations was scored for each rat, and this number was expressed as a percentage of the total CS presentation time. For analysis, freezing across each trial was averaged into a single score for each memory test. All data were analyzed with ANOVA and Duncan's post hoc $t$ tests. Differences were considered significant if $p<0.05$.

To verify whether ODN infusion might have produced delayed damage to the LA, antisense-infused rats were reconditioned ODN-free $\sim 1$ week later. As before, rats were retrained using a single conditioning trial consisting of a $30 \mathrm{~s}, 5 \mathrm{kHz}, 75 \mathrm{~dB}$ tone that coterminated with a $1.0 \mathrm{~s}, 1.5$ $\mathrm{mA}$ foot shock and retested for retention of auditory fear conditioning $\sim 24$ h later.

At the end of each behavioral experiment, rats were anesthetized by an overdose of chloral hydrate $(250 \mathrm{mg} / \mathrm{kg})$ and perfused with $10 \%$ buffered formalin. Nissl staining and light microscopy were used to verify the location of the cannula tips within the amygdala.

MEK inhibitor experiments. Cannulated rats were given an intra-LA infusion of either $0.5 \mu \mathrm{l}$ of 50\% DMSO (vehicle) or U0126 in 50\% DMSO $(1.0 \mu \mathrm{g} /$ side in $0.5 \mu \mathrm{l})$. U0126 (Promega) was dissolved in 100\% DMSO to a final stock concentration of $4 \mu \mathrm{g} / \mu \mathrm{l}$. For infusion, the drug was diluted 1:1 in ACSF. U0126 is a specific inhibitor of MAP kinase kinase (MEK), an upstream regulator of ERK/MAPK activation (Favata et al., 1998). The effects of U0126 have been shown to be specific to ERK/ MAPK and to have no effect at a range of concentrations on other kinases, such as PKA, calcium-calmodulin kinase II, or PKC (Roberson et al., 1999).

After infusion of vehicle or U0126, injectors remained in the guide cannulas for $1 \mathrm{~min}$ to allow diffusion of the drug from the tip. Rats were conditioned $30 \mathrm{~min}$ after infusion and killed $2 \mathrm{~h}$ after training by either decapitation or perfusion (as described above). For Western blotting experiments, amygdala punches taken from around the tip of the infusion cannulas were homogenized and processed for Arc/Arg3.1 protein as described above. Blots were then stripped with $0.2 \mathrm{NaOH}$ and reprobed with an antibody against phospho-ERK (Cell Signaling). To control for inconsistencies in loading, optical densities were normalized to 

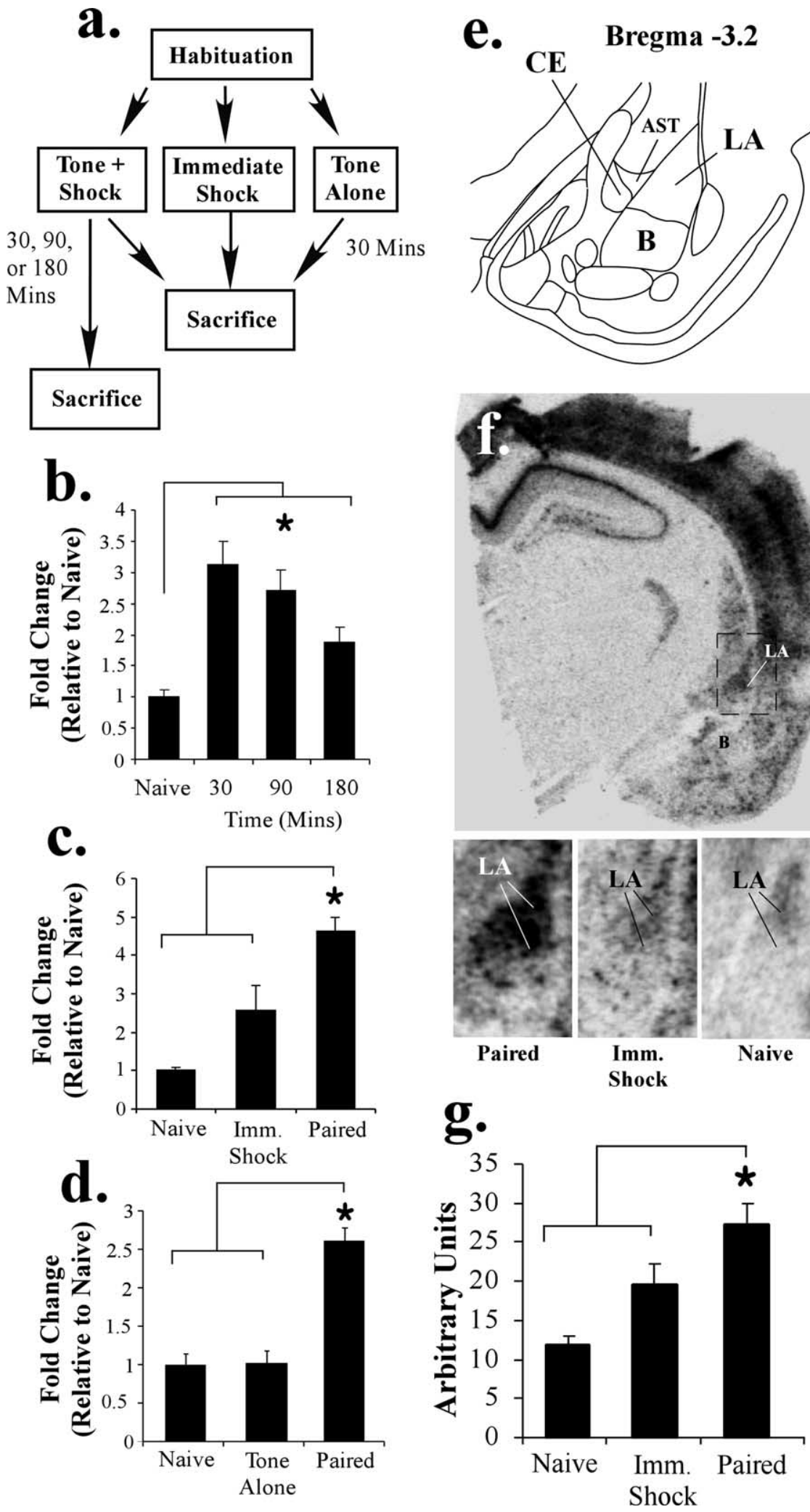

Figure 1. Fear conditioning regulates Arc/Arg3.1 mRNA in the lateral amygdala. $\boldsymbol{a}$, Schematic of the behavioral protocol. Rats were habituated to handling, conditioned with 3 pairings of a tone and shock, and killed at 30, 90, or 180 min after training. In other experiments, rats received either three tone-shock pairings (Paired), three immediate shocks (Imm. Shock), or three tones (Tone Alone), and were killed 30 min later. All groups were compared against a group of naive rats that had been handled but given no further stimulation (Naive). $\boldsymbol{b}$, Time course analysis of Arc/Arg3.1 mRNA expression in the LA after fear conditioning using qRT-PCR. Rats received 3 pairings of tone and shock and were killed at either 30,90 , or 180 min later $\left(n=8\right.$, each group). ${ }^{*} p<$ 0.05 relative to the naive group. C, Quantification of Arc mRNA in the LA of Paired $(n=7)$, Imm. Shock $(n=9)$, and Naive $(n=$ 8) groups using qRT-PCR. * $p<0.05$ relative to Naive and Imm. Shock groups. $d$, Quantification of Arc mRNA in the LA of Paired $(n=7)$, Tone Alone $(n=5)$, and Naive $(n=7)$ groups using qRT-PCR. ${ }^{*} p<0.05$ relative to Naive and Tone Alone groups. total ERK protein. Data for U0126 animals was normalized to the average value of vehicleinfused controls, and data were analyzed using ANOVA. For immunohistochemical experiments, brain sections containing the amygdala were processed for Arc/Arg3.1 protein as described above.

\section{Results}

Fear conditioning and LTP-inducing stimulation regulate transcription and translation of Arc/Arg3.1 in the lateral amygdala

Previous studies have shown that Arcl Arg3.1 is activated in an input-specific manner during hippocampal LTP (Steward et al., 1998; Moga et al., 2004) and required for hippocampal-dependent synaptic plasticity and memory formation (Guzowski et al., 2000). Although extensively studied in hippocampal learning, the role of Arc/Arg3.1 in amygdaladependent learning and memory has not received comparable attention. A recent study, however, showed that global genetic deletion of Arc/Arg3.1 impairs both contextual and auditory fear conditioning in mice (Plath et al., 2006), suggesting that Arc/Arg3.1 regulation in the LA during fear conditioning might be critical for fear memory consolidation and associated synaptic plasticity. In this first series of experiments, we therefore used a combination of qRT-PCR, in situ hybridization, Western blotting, and immunohistochemistry to examine whether auditory fear conditioning and LTP-inducing stimulation of thalamic input synapses to the LA regulate Arc/Arg3.1 mRNA and protein in the LA.

Auditory fear conditioning regulates Arc/ Arg3.1 mRNA in the LA

The findings of our Arc/Arg3.1 mRNA experiments are presented in Figure 1. In these experiments, we first examined the time course of Arc/Arg3.1 mRNA expression in the LA after fear conditioning. Rats were given 3 tone-shock pairings and killed either 30, 90, or 180 min after training. Relative to naive controls, we observed a peak of Arc/Arg3.1 mRNA at 30

$\boldsymbol{e}$, A representative diagram of the amygdala at $\sim$ Bregma -3.2 showing the location of the lateral nucleus $(L A)$, the basal nucleus (B), and the central nucleus of the amygdala (CE). The amygdala-striatal transition zone (AST) is also depicted. $\boldsymbol{f}$, Representative autoradiogram of a rat brain hemisection depicting Arc/Arg3.1 mRNA expression after fear conditioning. The box depicts the location of the LA. Higher level magnification of sections containing the LA from Paired, Imm. Shock, and Naive rats are presented below. $\boldsymbol{g}$, Quantification of Arc/Arg3.1 mRNA in the LA of Paired ( $n=7), \mathrm{Imm}$. Shock $(n=7)$, and Naive $(n=6)$ groups using in situ hybridization. ${ }^{*} p<0.05$ relative to Naive and $I \mathrm{~mm}$. Shock groups. 
min after fear conditioning using qRT-PCR (Fig. 1b). The ANOVA revealed a significant effect for group $\left[F_{(3,28)}=14.99\right.$, $p<0.01$ ], with the $30 \mathrm{~min}$ group being significantly different from both naive controls and the 180 min group $(p<0.05$; Duncan's test). The 90 and 180 min groups also differed from naive controls $(p<0.05)$, but did not differ significantly from each other $(p>0.05)$. Thus, fear conditioning appears to induce a slowly decaying wave of Arc/Arg3.1 gene expression in the LA that peaks at $30 \mathrm{~min}$ after training.

Next, we used qRT-PCR and in situ hybridization to examine whether training-induced regulation of Arc/Arg3.1 mRNA in the LA is specific to associative fear learning rather than exposure to either tone or shock alone. Rats were given 3 tone-shock pairings as before and killed $30 \mathrm{~min}$ after conditioning. As a control, a separate group of rats was exposed to 3 immediate shocks of equivalent duration and intensity, a protocol that does not support fear conditioning (Fanselow, 1980). In a separate experiment, rats receiving 3 tone-shock pairings were compared against those receiving presentation of 3 tones in the absence of shock. In each experiment, all groups were compared with a naive control group. In the LA, qRT-PCR revealed that fear conditioning leads to a significant increase in Arc/Arg3.1 mRNA relative to immediate shock and naive controls (Fig. 1c). The ANOVA revealed a significant effect for group $\left[F_{(2,21)}=39.9, p<0.01\right]$, with the paired group being significantly different from both immediate shock and naive controls ( $p<0.05$; Duncan's test). The immediate shock group was also observed to differ from naive controls $(p<0.05)$, showing an intermediate level of Arc/Arg3.1 mRNA expression between controls and paired animals. Presentation of tone alone, however, failed to regulate Arc/Arg3.1 mRNA expression in the LA (Fig. 1d). The ANOVA revealed a significant effect for group $\left[F_{(2,16)}=12.18, p<0.01\right]$, with the paired group being significantly different from both tone alone and naive controls ( $p<0.05$; Duncan's test). The tone alone group did not differ from naive controls ( $p>0.05$ ).

A representative photomicrograph of Arc/Arg3.1 mRNA expression in a coronal hemisection from a paired rat is presented in Figure $1 f$. Higher level magnifications of Arc/Arg3.1 expression in the LA from paired, immediate shock, and naive animals are depicted below. Arc/Arg3.1 mRNA was observed to be robustly expressed in the cortex and CA subfields of the hippocampus. In the LA, Arc/Arg3.1 mRNA appeared to be most robustly expressed in the dorsal regions of the LAd and extending diffusely into the ventral LA. Consistent with the qRT-PCR data, we observed a significant elevation in Arc/Arg3.1 mRNA in the LA relative to immediate shock and naive controls (Fig. 1g). The ANOVA revealed a significant effect for group $\left[F_{(2,17)}=10.19\right.$, $p<0.01]$, with the paired group being significantly different from the immediate shock and naive controls ( $p<0.05$; Duncan's test). The immediate shock group was also observed to differ from naive controls $(p<0.05)$.

Auditory fear conditioning regulates Arc/Arg3.1 protein in the LA The findings of our Arc/Arg3.1 protein experiments are presented in Figure 2. In these experiments, we exposed rats to either 3 tone-shock pairings or to 3 immediate shocks as in our mRNA experiments, followed by killing $2 \mathrm{~h}$ later (Fig. $2 a$ ).

Using Western blotting, we observed a significant increase in Arc/Arg3.1 protein expression in LA homogenates relative to immediate shock and naive controls (Fig. $2 b$ ). The ANOVA revealed a significant effect for group $\left[F_{(2,16)}=5.86, p<0.02\right]$, with the paired group being significantly different from both immediate shock and naive controls ( $p<0.05$; Duncan's test). There were no significant differences between naive and immediate shock groups $(p>0.05)$. The levels of the loading control GAPDH, however, failed to differ between groups, $F_{(2,16)}=1.55$ (data not shown), suggesting that protein lysate loading was equivalent among the three groups.

Our immunohistochemical findings are presented in Figure $2 c-h$. We observed Arc/Arg3.1 labeled cells throughout the LA and adjacent cortical regions. Labeling was also observed in the adjacent basal nucleus (B), whereas that in the central nucleus of the amygdala (CE) was low. Labeling in the LA appeared to be most prominent in the dorsal regions of the LA, extending into the ventral portions of LAd and also into LAvl. There were also a few labeled cells in LAvm. Representative photomicrographs from paired, immediate shock, and naive rats can be viewed in Figure $2 c-e$, and higher magnification photomicrographs from a paired rat are presented in Figure $2 f, g$. Cell counts from the LA (including LAd, LAvl, and LAvm), the CE, and the basal nucleus can be viewed in Figure $2 h$. Statistical analysis on cell counts revealed that Arc/Arg3.1 labeling was significantly increased in the LA in paired animals relative to immediate shock or naive conditions. The ANOVA revealed a significant effect for group $\left[F_{(2,6)}=26.35, p<0.01\right]$, with the paired group being significantly different from immediate shock and naive controls $(p<$ 0.05; Duncan's test). There were no significant differences between naive and immediate shock groups $(p>0.05)$. A similar pattern of findings was observed for the basal nucleus. The ANOVA revealed a significant effect for group $\left[F_{(2,6)}=12.47\right.$, $p<0.01$ ], with the paired group being significantly different from immediate shock and naive controls ( $p<0.05$; Duncan's test). There were no significant differences between naive and immediate shock groups $(p>0.05)$. In the $\mathrm{CE}$, however, no significant elevation in Arc/Arg3.1 was observed. The ANOVA revealed no significant effects $\left[F_{(2,6)}=2.43, p>0.05\right]$.

LTP-inducing stimulation of thalamo-LA synapses regulates Arc/ Arg3.1 mRNA and protein in the LA

In the first series of experiments, we examined the regulation of Arc/Arg3.1 mRNA and protein after auditory fear conditioning. Here, we examined Arc/Arg3.1 regulation after LTP-inducing stimulation of auditory thalamic inputs to the LA. We focused on thalamic inputs because this pathway has been the most extensively characterized at the pharmacological level and has been shown to exhibit the longevity properties in LTP that are desirable as a mechanism of long-term memory formation (Doyère et al., 2003).

In these experiments, rats received either high-frequency stimulation (HFS) or low-frequency stimulation (LFS) of thalamic inputs to the LA as described above (see Materials and Methods) and were killed by decapitation or perfusion either 30 min (in situ experiments) or $2 \mathrm{~h}$ later (Western blot experiments). We and others have recently shown that this HFS protocol reliably induces LTP in the LA that lasts for at least $60 \mathrm{~min}$ (Yaniv et al., 2000, 2001; Doyère et al., 2003; Schafe et al., 2008), whereas the LFS protocol produces no LTP (Schafe et al., 2008).

A representative photomicrograph of Arc/Arg3.1 mRNA expression in a coronal section from a rat that received HFS is presented in Figure 3a. Higher level magnifications of Arc/Arg3.1 expression in the LA from rats receiving HFS and LFS on the side ipsilateral to the simulation are depicted to the right. Arc/Arg3.1 mRNA was robustly expressed on the stimulated side of the brain, including in most regions of the cortex and within CA1 subfields. In the LA, high-frequency stimulation induced a robust activation of Arc/Arg3.1 mRNA ipsilateral to the stimulation (Fig. 3b). 
Relative to the contralateral side of the brain, this activation was significantly different, $t_{(5)}=6.12, p<0.01$. In contrast, LFS did not lead to elevations in Arc/ Arg3.1 mRNA expression in the LA, $t_{(5)}=$ $0.16, p>0.05$. Further, HFS rats differed significantly from LFS rats on the stimulated side of the brain, $t_{(10)}=8.62, p<$ 0.01 . This same pattern of findings was observed in the Western blotting experiment (Fig. $3 c$ ). Relative to the contralateral side of the brain, we observed significantly higher levels of Arc/Arg3.1 protein in LA homogenates from HFS rats $\left[t_{(7)}=5.53\right.$, $p<0.01]$, but homogenates from LFS rats failed to differ significantly from the contralateral side $\left[t_{(3)}=1.43\right]$. Further, HFS rats differed significantly from LFS rats on the stimulated side of the brain, $t_{(10)}=$ $2.42, p<0.05$. Levels of the loading control GAPDH, however, failed to differ between the two sides for HFS $\left[t_{(7)}=1.30\right]$ or LFS $\left[t_{(3)}=0.89\right]$ rats (data not shown).

Immunohistochemical localization of Arc/Arg3.1 after HFS and LFS can be seen in Figure 3d,e. High-frequency stimulation induced robust expression of Arc/ Arg3.1 in the LA that was prominent in both the dorsal LAd and extending into the more ventral portions of the LAd and LAvl (Fig. $3 d$ ). In contrast, LFS produced little Arc/Arg3.1 expression in the LA (Fig. 3e). Higher level magnification images from an HFS rat can be observed in Figure $3 f, g$. Interestingly, the CE exhibited high levels of Arc/Arg3.1 expression that did not appear to vary as a function of stimulation condition (Fig. 3d,e). This same pattern of findings was also observed in the mRNA experiments, and even on the contralateral side of the brain (Fig. 3a). Importantly, we did not observe a comparable level of Arc/ Arg3.1 mRNA or protein expression in the CE of our awake/behaving rats (Figs. 1, 2), which might suggest that labeling in the CE may have been an artifact of urethaneinduced anesthesia.

Together with our previous observations, these findings indicate that both auditory fear conditioning and synaptic plasticity at thalamo-LA inputs induce Arc/ Arg3.1 mRNA and protein in the LA.

\section{Antisense knockdown of Arc/Arg3.1 in the lateral amygdala impairs fear memory consolidation}

Our initial series of experiments showed that Arc/Arg3.1 mRNA and protein were regulated in the LA by fear conditioning and by LTP-inducing stimulation of LA synapses. In this series of experiments, we asked whether Arc/Arg3.1 was obligatory for fear memory consolidation using local-
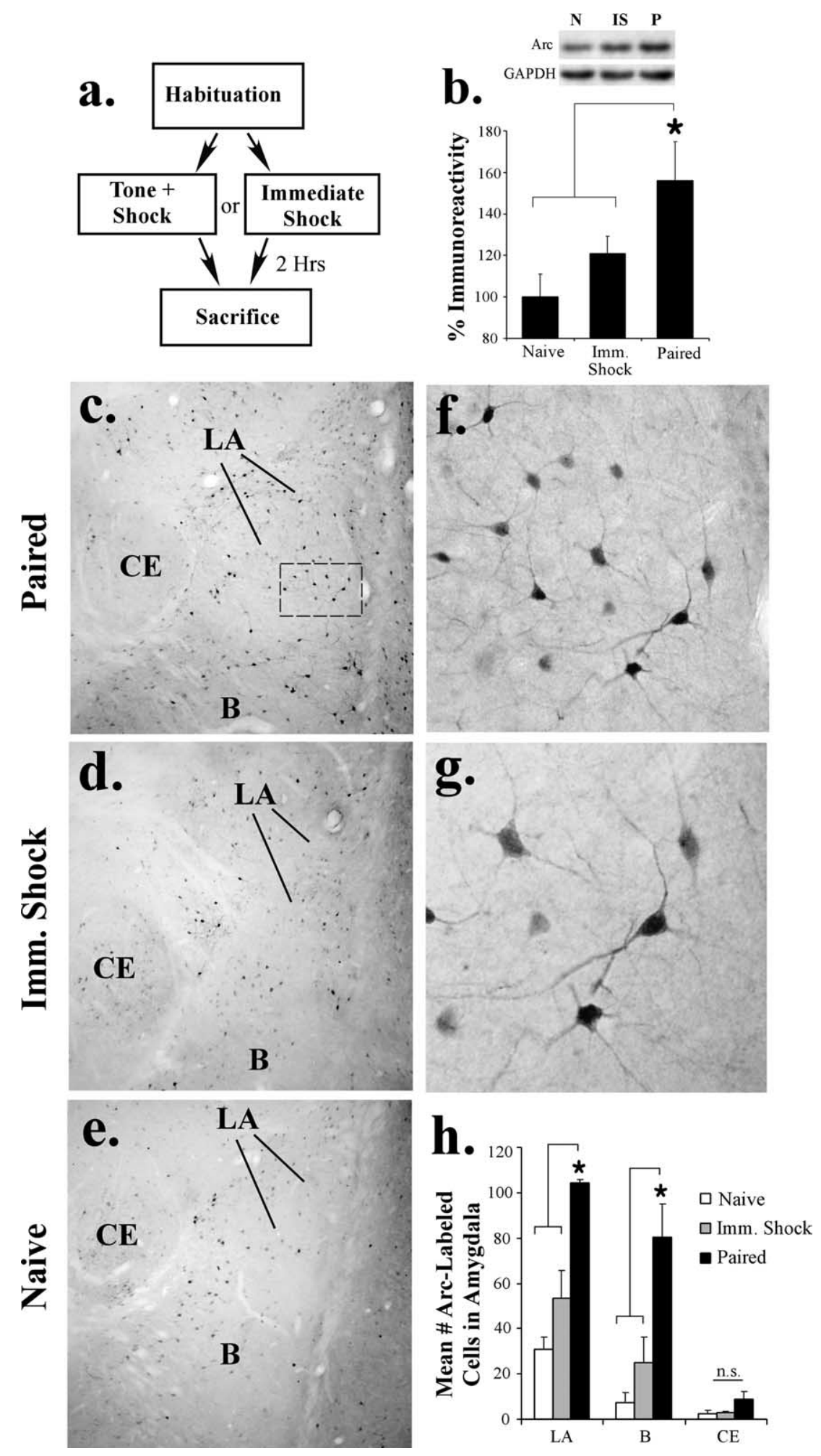

Figure 2. Fear conditioning regulates Arc/Arg3.1 protein in the lateral amygdala. $\boldsymbol{a}$, Schematic of the behavioral protocol. Rats were habituated to handling for $2 \mathrm{~d}$, trained with 3 pairings of a tone and shock (Paired), and killed $2 \mathrm{~h}$ later. Control animals received handling for $2 \mathrm{~d}$ followed by 3 immediate shocks (Imm. Shock) and were killed $2 \mathrm{~h}$ later. A third group consisted of naive rats that had been handled but given no further stimulation (Naive). $\boldsymbol{b}$, Western blot analysis of Arc/Arg3.1 protein in the LA of Paired $(n=6)$, Imm. Shock $(n=7)$, and Naive $(n=6)$ groups after fear conditioning. ${ }^{*} p<0.05$ relative to Naive and Imm. Shock groups. Representative blots can be seen in the inset. $\boldsymbol{c}-\boldsymbol{e}$, Representative $10 \times$ photomicrographs of immunolabeled Arc/Arg3.1 neurons in a Paired, Imm. Shock, and Naive rat, respectively. $\boldsymbol{f}, \boldsymbol{g}$, Higher level (20 and $40 \times$, respectively) magnifications of Arc/Arg3.1 labeled neurons from the box in the Paired rat in c. Note that Arc/Arg3.1 label is present throughout the soma, dendrites, and nucleus of LA cells. $\boldsymbol{h}$, Quantification of Arc/Arg3. 1 labeled cells in the LA, CE, and basal nucleus (B) of the amygdala of Paired $(n=3)$, Imm. Shock $(n=3)$, and Naive $(n=3)$ groups after fear conditioning. ${ }^{*} p<0.05$ relative to Naive and Imm. Shock groups. 

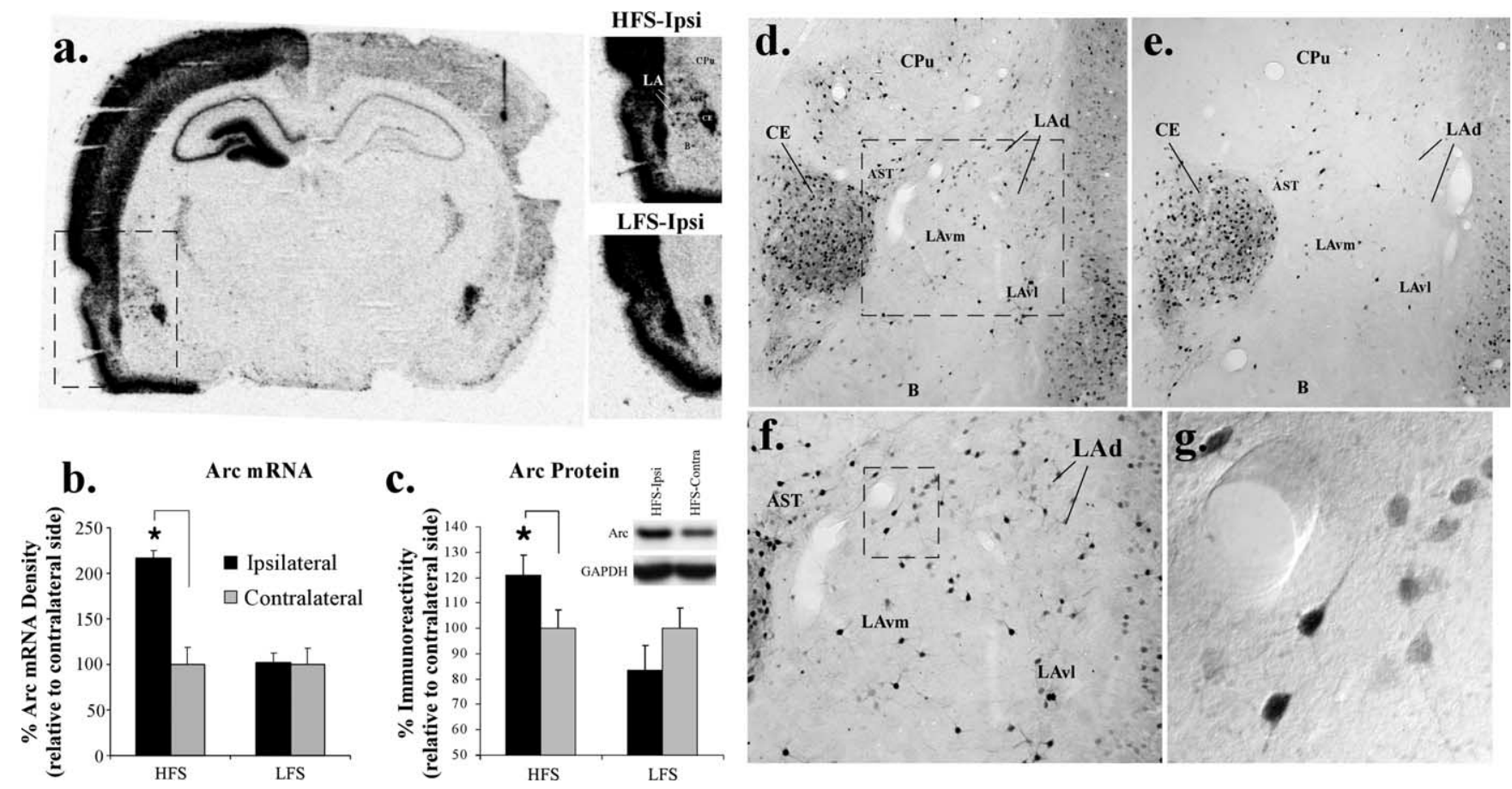

Figure 3. LTP-inducing stimulation of thalamo-LA synapses regulates Arc/Arg3.1 mRNA and protein in the lateral amygdala. $\boldsymbol{a}$, Representative autoradiogram of a rat brain section depicting Arc/Arg3.1 mRNA expression after HFS of the auditory thalamus. The box depicts the location of the LA on the stimulated side of the brain. Higher level magnification of sections containing the ipsilateral LA from HFS and LFS rats are presented to the right. $\boldsymbol{b}$, Quantification of Arc/Arg3.1 mRNA in the LA of HFS $(n=6)$ and LFS ( $n=6) \mathrm{groups}$. The black bar represents the LA ipsilateral to the stimulation, whereas the gray bar represents the contralateral (nonstimulated) LA. ${ }^{*} p<0.05$ relative to the contralateral side. $c$, Western blot analysis of Arc/Arg3.1 protein in the LA of HFS ( $n=$ 8) and LFS $(n=4)$ groups. The black bar represents the LA ipsilateral to the stimulation, whereas the gray bar represents the contralateral (nonstimulated) LA. ${ }^{*} p<0.05$ relative to the contralateral side. Representative blots can be depicted in the inset. $\boldsymbol{d}, \boldsymbol{e}$, Representative $10 \times$ photomicrographs of immunolabeled Arc/Arg3.1 neurons in an HFS and LFS rat, respectively. $\boldsymbol{f}, \boldsymbol{g}$, Higher level (20 and $40 \times$, respectively) magnifications of Arc/Arg3.1 labeled neurons from the box in the HFS rat in d. Note, as with fear conditioning, that Arc/Arg3.1 label is present throughout the soma, dendrites, and nucleus of LA cells.

ized antisense oligodeoxynucleotide (ODN) knockdown of Arc/ Arg3.1 protein in the LA. In the first series of experiments, we used a biotinylated Arc/Arg3.1 ODN to assay the extent of Arc/ Arg3.1 antisense ODN diffusion throughout the LA. Next, we examined whether intra-LA infusion of Arc/Arg3.1 antisense ODN produced significant knockdown of Arc protein in the LA. Finally, we asked whether knockdown of Arc/Arg3.1 in the LA impairs fear memory consolidation.

Arc/Arg3.1 ODN is anatomically confined to the LA and promotes significant knockdown of Arc protein

Figure $4 a-c$ depicts the diffusion of biotinylated Arc/Arg3.1 antisense ODN at three rostrocaudal levels of the LA three $h$ after infusion $(2 \mathrm{nmol} ; 1 \mu \mathrm{l})$. At each level, the ODN remained remarkably confined to the borders of the LA, largely sparing both the central nucleus of the amygdala (CE), the basal nucleus of the amygdala (B), and the adjacent perirhinal cortex. At higher magnification, Arc/Arg3.1 antisense ODN was observed to be localized to cell bodies and dendrites in the LA, indicating that the ODN was actively taken up by cells (Fig. $4 d$,e). Labeling of the biotinylated Arc/Arg3.1 ODN was less pronounced at 6 and $24 \mathrm{~h}$ after infusion (data not shown).

Arc/Arg3.1 protein knockdown is depicted in Figure $4 f$. In these experiments, rats received intra-LA infusion of either antisense (AS) or scrambled (S) ODN (2 nmol; $1 \mu \mathrm{l})$ on opposite sides of the brain and were killed at 3, 6, or $24 \mathrm{~h}$ later. The analysis revealed a significant knockdown of Arc/Arg3.1 protein $6 \mathrm{~h}$ after infusion, $t_{(12)}=2.95, p<0.02$. There was no significant effect of the antisense ODN infusion at either $3 \mathrm{~h}\left[t_{(10)}=0.10, p>0.05\right]$ or $24 \mathrm{~h}\left[t_{(10)}=0.10, p>0.05\right]$ after infusion.
Collectively, these findings indicate that Arc/Arg3.1 ODN is anatomically restricted to the LA after infusion of this dose and volume, taken up by LA cells, and results in significant and transient knockdown of Arc/Arg3.1 protein. Furthermore, our findings suggest that although Arc/Arg3.1 ODN is maximally expressed in cells of the LA at $3 \mathrm{~h}$ after infusion, the effects of the ODN on Arc/Arg3.1 protein expression are not evident until at least $6 \mathrm{~h}$ later.

Impaired fear memory consolidation after Arc/Arg3.1 knockdown in the LA

The findings of the behavioral experiments are presented in Figure 5. In these experiments, we infused rats with one of two doses of either scrambled or Arc/Arg3.1 antisense ODN $6 \mathrm{~h}$ before fear conditioning $(0.2$ or $2 \mathrm{nmol} ; 1 \mu \mathrm{l})$, and then tested each rat for retention of auditory fear conditioning at both $3 \mathrm{~h}$ (STM) and $24 \mathrm{~h}$ (LTM) later.

Rats infused with either scrambled or Arc/Arg3.1 antisense ODN had intact postshock freezing after training (Fig. 5b). The ANOVA revealed only a significant effect of time (pretraining vs posttraining), $F_{(1,24)}=169.89, p<0.05$. The effect of group $\left[F_{(1,24)}=0.80\right]$, dose $\left[F_{(1,24)}=0.51\right]$, and the interactions (group by dose, $\left[F_{(1,24)}=0.87\right]$; group by time, $\left[F_{(1,24)}=0.80\right]$; dose by time, $\left[F_{(1,24)}=0.51\right]$; group by dose by time, $\left[F_{(1,24)}=0.87\right]$ ) were not significant. Similarly, each group had intact STM when tested for auditory fear memory $3 \mathrm{~h}$ after training (Fig. $5 c$ ). The ANOVA (group by dose) revealed no significant effect of group $\left[F_{(1,24)}=0.04\right]$, dose $\left[F_{(1,24)}=0.23\right]$, or group by dose interaction $\left[F_{(1,24)}=0.01\right]$. Thus, knockdown of Arc protein in the LA has no 
effect on acquisition or STM formation of auditory fear conditioning.

In contrast to the STM test, both groups infused with Arc/Arg3.1 antisense ODN had impaired LTM relative to scrambled controls (Fig. 5d). The ANOVA (group by dose) revealed a significant effect of group, $F_{(1,24)}=5.45, p<0.03$. The effect of dose $\left[F_{(1,24)}=0.20\right]$ and the group by dose interaction $\left[F_{(1,24)}=0.01\right]$ did not reach significance. To further analyze this effect, we expressed each animal's LTM score as a percentage of its STM score (Fig. $5 e$ ). The ANOVA (group by dose) revealed a significant effect of group, $F_{(1,24)}=9.87$, $p<0.01$. The effect of dose $\left[F_{(1,24)}=0.24\right]$ and the group by dose interaction $\left[F_{(1,24)}\right.$ $=0.05]$ did not reach significance. Thus, although knockdown of Arc/Arg3.1 protein in the LA has no effect on acquisition or STM formation of auditory fear conditioning, LTM is significantly impaired.

Importantly, animals infused with the highest dose of Arc/Arg3.1 antisense ODN were capable of relearning the fear association $\sim 1$ week later. Rats were retrained ODN free, then retested for retention of auditory fear conditioning (Fig. 5d). Relative to their first LTM test, antisenseinfused rats exhibited significantly higher freezing scores at retest $\left[t_{(6)}=3.08, p<\right.$ 0.03 ], which did not differ significantly from the amount of freezing exhibited by scrambled controls in the first test, $t_{(11)}=$ $1.10, p>0.05$. Thus, the memory impairments observed in the Arc/Arg3.1 antisense ODN-infused rats cannot be attributable to damage to the LA that emerged late in the consolidation process.

Histological verification of the cannula placements for rats infused with either scrambled or Arc/Arg3.1 antisense ODNs are depicted in Figure $5 f$. Cannula tips were observed to lie throughout the LA at various rostrocaudal levels. Only rats with cannula tips at or within the boundaries of the LA were included for data analysis.

\section{Arc/Arg3.1 regulation is downstream of ERK/MAPK activation in the lateral amygdala}

In our behavioral experiments, we determined that antisense knockdown of Arc/ Arg3.1 impairs memory consolidation of auditory fear conditioning. In this final experiment, we asked whether traininginduced expression of Arc/Arg3.1 might be downstream of activation of the extracellular-signal regulated kinase/mitogenactivated protein kinase (ERK/MAPK) signaling pathway. The ERK/MAPK signaling pathway has been widely implicated in both synaptic plasticity (English and Sweatt, 1996, 1997; Impey et al., 1998, 1999; Davis et al., 2000; Sweatt, 2004) and in memory consolidation (Brambilla et al., 1997; Atkins et al., 1998; Blum et al., 1999; Schafe et al., 1999), including fear memory consolida-
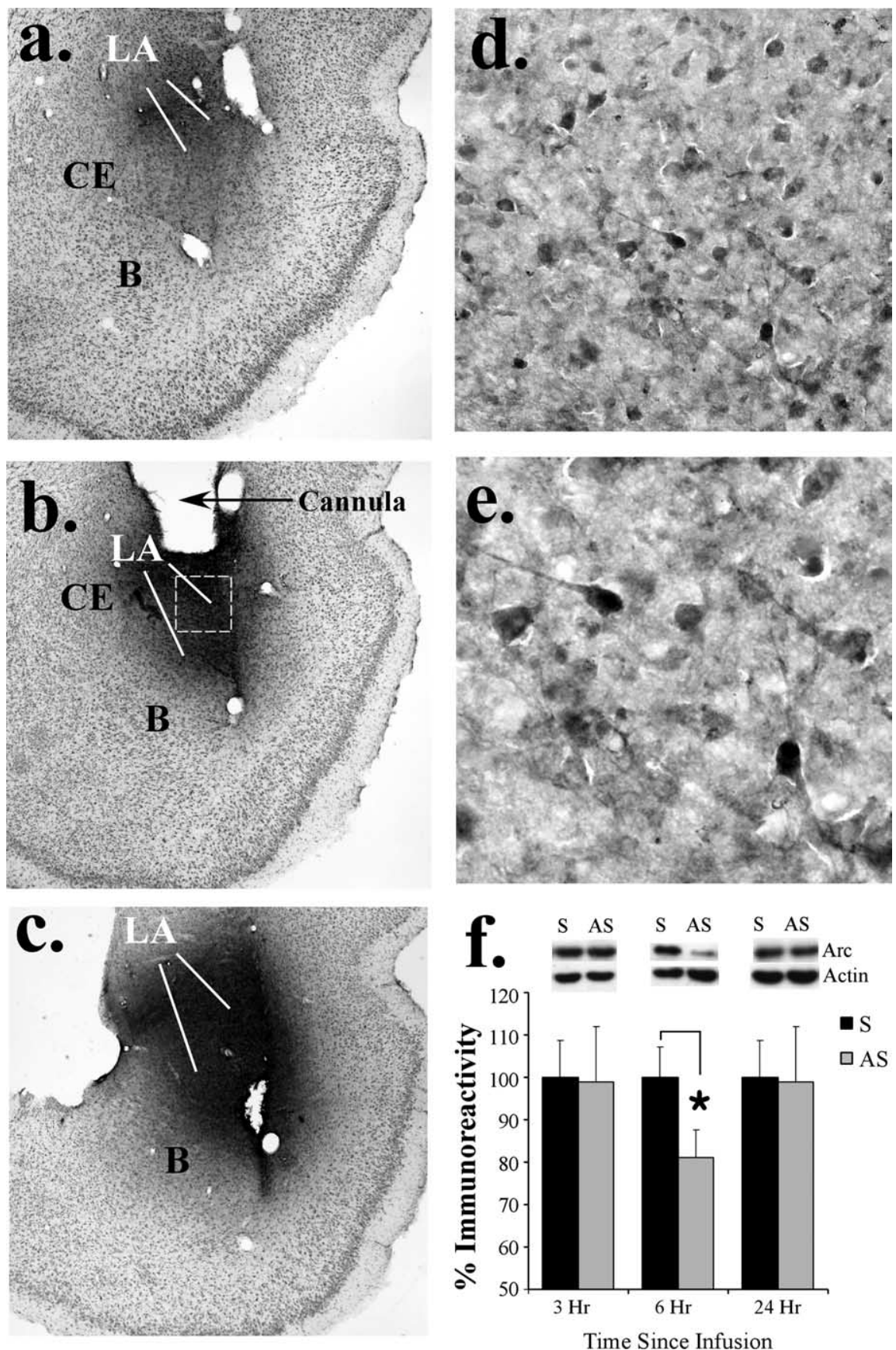

Figure 4. Antisense ODN knockdown of Arc/Arg3.1 protein in the LA. $\boldsymbol{a}-\boldsymbol{c}$, Representative $10 \times$ photomicrographs at three rostro-caudal levels of an animal infused with biotinylated Arc/Arg3.1 ODN ( $1 \mu \mathrm{l} ; 2 \mathrm{nmol}$ ) and killed $3 \mathrm{~h}$ later. Note that the ODN diffusion is largely restricted to the LA and spares the basal and central nuclei of the amygdala. $\boldsymbol{d}, \boldsymbol{e}$, Higher level ( 20 and $40 \times$, respectively) magnifications of $L A$ neurons containing biotinylated Arc/Arg3.1 ODN label from the box in $\boldsymbol{b}$. Note the large number of cells exhibiting uptake of the ODN. $\boldsymbol{f}$, Arc/Arg3.1 protein from LA homogenates in rats killed either $3(n=11), 6(n=13)$, or $24 \mathrm{~h}$ $(n=11)$ after infusion of either scrambled or antisense 0DNs. ${ }^{*} p<0.05$ relative to the scrambled 0DN-infused side.

tion in the LA (Schafe et al., 2000, 2005). Furthermore, recent studies have shown that activation of the ERK/MAPK signaling pathway regulates the transcription of Arc/Arg3.1 (Waltereit et al., 2001), as well as targeting of newly synthesized Arc/Arg3.1 mRNAs to synaptic sites (Huang et al., 2007).

In our experiments, rats were given bilateral intra-LA infusion of the MEK inhibitor U0126 ( $1 \mu \mathrm{g} /$ side), a dose that has previously been shown to effectively impair ERK/MAPK activation and memory consolidation of auditory fear conditioning (Schafe et al., 2000) and the consolidation of training-induced synaptic 

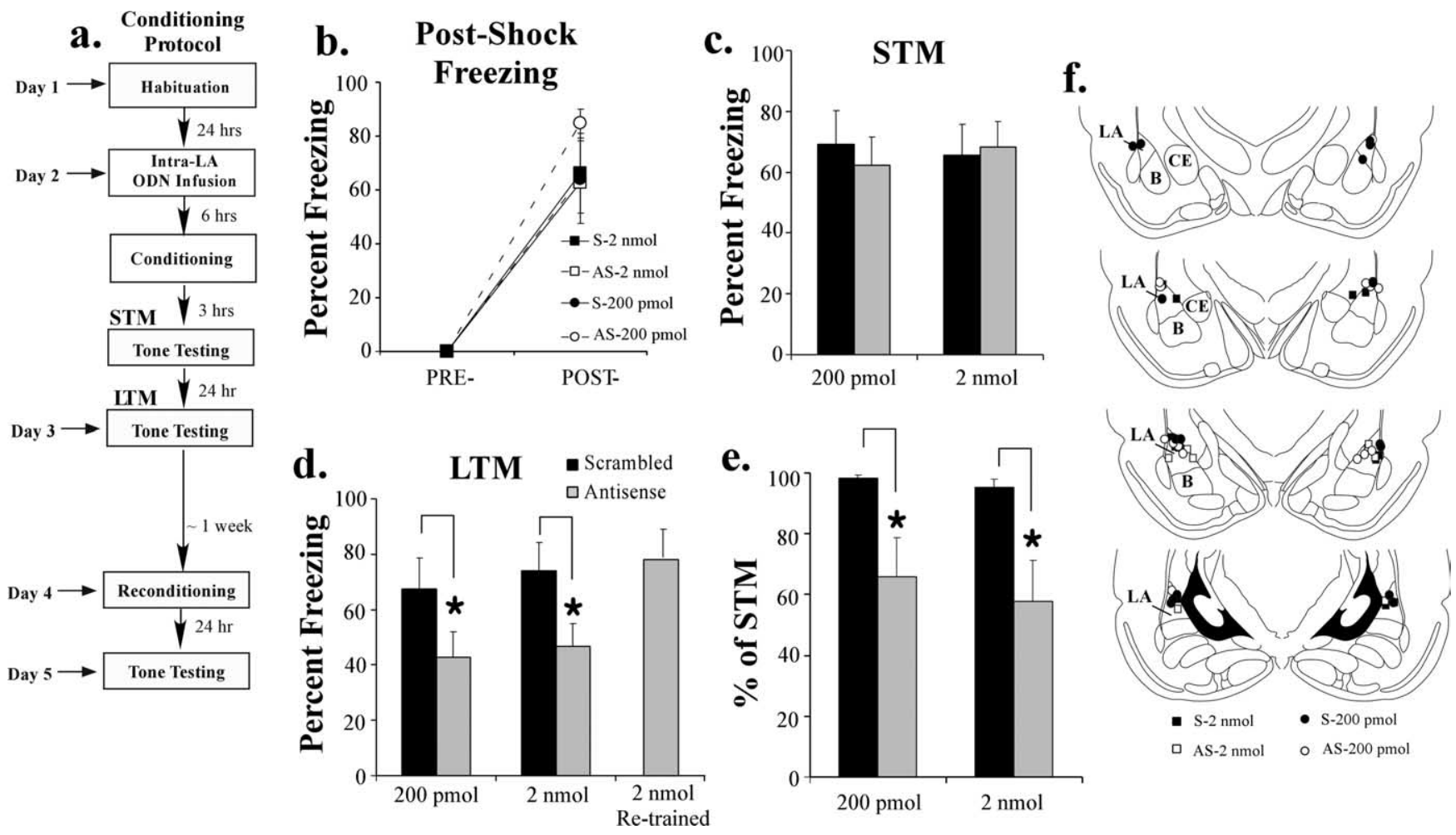

Figure 5. Antisense knockdown of Arc/Arg3.1 protein in the LA impairs memory consolidation of auditory fear conditioning. $\boldsymbol{a}$, Schematic of the behavioral protocol. Rats were infused (1 $\mu$ l/side) with one of two doses of scrambled ODN ( $200 \mathrm{pmol}, n=7$ or $2 \mathrm{nmol}, n=6)$, or one of two doses of Arc/Arg3.1 antisense ODN (200 pmol, $n=8$ or $2 \mathrm{nmol}, n=7) 6 \mathrm{~h}$ before fear conditioning consisting of 1 tone-shock pairing. $\boldsymbol{b}$, Postshock freezing scores in each group immediately after the conditioning trial. $\boldsymbol{c}$, Auditory fear memory assessed at $3 \mathrm{~h}$ after fear conditioning in each group. The black bars represent the scrambled ODN-infused groups, whereas the gray bars represent the antisense-infused groups. $\boldsymbol{d}$, Auditory fear memory assessed at $24 \mathrm{~h}$ after fear conditioning in each group. ${ }^{*} p<0.05$ relative to the scrambled $0 \mathrm{DN}$-infused groups. Also depicted are the memory retest scores for rats in the $2 \mathrm{nmol}$ of Arc/Arg3.1 antisense group that were reconditioned drug-free $\sim 1$ week later. $\boldsymbol{e}$, Data depicting LTM as a percentage of STM for each rat in each group. ${ }^{*} p<0.05$ relative to the scrambled ODN-infused groups. $\boldsymbol{f}$, Histological verification of cannula placements for rats infused with $200 \mathrm{pmol}$ of scrambled ODN (black circles), $200 \mathrm{pmol}$ of Arc/Arg3.1 antisense ODN (white circles), $2 \mathrm{nmol}$ of scrambled ODN (black squares) or $2 \mathrm{nmol}$ of Arc/Arg3.1 antisense 0DN (white squares). Panels were adapted from Paxinos and Watson (1997).

plasticity in the LA (Schafe et al., 2005). Thirty minutes later, rats were conditioned with 3 tone-shock pairings as before and killed $2 \mathrm{~h}$ later by either decapitation or perfusion (Fig. 6a). In Western blotting experiments, Arc/Arg3.1 protein expression was examined in homogenates taken from around the cannula tips. To verify the effectiveness of U0126 in impairing ERK/MAPK activation in each sample, we also probed the blots with an antiphospho-ERK antibody. In immunohistochemical experiments, brain slices containing the LA were processed using an anti-Arc/ Arg3.1 antibody as above.

The findings of the Western blotting experiment are presented in Figure $6 b$. Relative to Vehicle-infused controls, rats infused with U0126 exhibited significantly lower expression of both Arc/ Arg3.1 and activated ERK/MAPK in the LA after fear learning. The ANOVA (drug group by protein) revealed a significant effect for drug $\left[F_{(1,20)}=13.39, p<0.01\right]$. The effect for protein $\left[F_{(1,20)}\right.$ $=0.53]$ and the drug by protein interaction $\left[F_{(1,20)}=0.53\right]$ were not significant. Further, both groups (vehicle, U0126) exhibited equivalent expression of total (unphosphorylated) ERK/MAPK, $t_{(10)}=1.70, p>0.05$ (data not shown), indicating that the reduction in Arc and phospho-ERK protein was not caused by druginduced alterations in total protein.

The findings of the immunohistochemical experiment are presented in Figure $6 c-e$. Relative to Vehicle-infused controls, rats infused with U0126 exhibited significantly lower expression of Arc/Arg3.1 labeled cells in the LA after fear learning $\left[t_{(6)}=\right.$ 8.30, $p<0.01]$. Cannula placements for animals infused with either Vehicle or U0126 can be observed in Figure $6 f$. Only rats with cannula tips at or within the boundaries of the LA were included for data analysis.

Thus, ERK/MAPK activation appears to be upstream of training-induced elevations in Arc/Arg3.1 expression in the LA.

\section{Discussion}

In the present study, we examined the role of the immediate early gene Arc/Arg3.1 in fear memory consolidation and synaptic plasticity in the LA using a combination of biochemical, immunohistochemical, and behavioral methods. Arc/Arg.3.1 has been extensively studied in hippocampal-dependent learning and synaptic plasticity (Guzowski and McGaugh, 1997; Steward et al., 1998; Guzowski et al., 2000; Steward and Worley, 2001a), but little is known about its role in other types of learning and memory. A recent study, however, indicated that mice with a global knockout of Arc/Arg3.1 exhibit impaired long-term memory of contextual and auditory fear conditioning (Plath et al., 2006). Consistent with that finding, we report here that Arc/Arg3.1 mRNA and protein is transiently expressed in the LA after both fear conditioning and LTP-inducing stimulation of thalamic inputs to the LA. Furthermore, antisense knockdown of Arc/Arg3.1 protein in the LA impairs memory consolidation; that is, LTM is impaired, whereas STM is intact. Finally, we show that intra-LA infusion of the MEK inhibitor U0126 impairs training-induced expression of Arc/Arg3.1 in the LA. Collectively, our findings strongly favor the 
view that ERK-driven expression of Arc/ Arg3.1 underlies fear memory consolidation in the amygdala.

A considerable amount of work has focused on glutamatergic signaling, protein kinase signaling pathways and transcription factors in the amygdala that are critical for fear conditioning (Miserendino et al., 1990; Schafe et al., 2000; Schafe and LeDoux, 2000; Josselyn et al., 2001; Lin et al., 2001; Rodrigues et al., 2001, 2002, 2004a,b). Surprisingly little is known, however, about the downstream genes that underlie long-term storage of fear memories in the LA. A number of studies have examined IEG regulation in the hippocampus after either contextual (Radulovic et al., 1998; von Hertzen and Giese, 2005; Huff et al., 2006) or cued fear conditioning (Radulovic et al., 1998; Ressler et al., 2002). Other studies have examined IEG regulation in either hippocampus (Hall et al., 2001a; Strekalova et al., 2003; von Hertzen and Giese, 2005) or amygdala (Hall et al., 2001a,b) after retrieval of a fear memory. Of those studies that have examined the role of IEGs in the amygdala after fear conditioning, most have done so using contextual fear conditioning tasks (Beck and Fibiger, 1995; Rosen et al., 1998; Malkani and Rosen, 2000a,b, Scicli et al., 2004). Several studies, however, have observed associative increases in the expression of the IEGs Fos and early growth response gene 1 (EGR-1) in the amygdala after cued fear conditioning (Radulovic et al., 1998; Radwanska et al., 2002; Ressler et al., 2002). Furthermore, Malkani et al., recently showed that antisense knockdown of EGR-1 in the LA impairs memory formation of contextual fear conditioning (Malkani et al., 2004), which to date is the only study, of which we are aware, that has attempted to examine the functional significance of IEG regulation in the amygdala after fear learning. Together with the data presented here, these studies represent the first look at the role of downstream genes in memory formation of Pavlovian fear learning in the LA.

Our immunohistochemical analyses also found $\operatorname{Arc} / \operatorname{Arg} 3.1$ to be regulated in the basal, but not the central, nucleus of the amygdala after fear conditioning. The increase in Arc/Arg3.1 in the basal nucleus may at first seem surprising, given that selective lesions of the basal amygdala fail to affect auditory fear conditioning (Nader et al., 2001; Amorapanth et al., 2000). However, it is possible that training-induced alterations in Arc/Arg3.1 in the basal nucleus reflect plasticity related to contextual fear conditioning (Maren and Fanselow, 1995; Goosens and Maren, 2001). Further, a recent study has suggested that the basal amygdala plays a more essential role in auditory fear conditioning than previously appreciated (Anglada-Figueroa and Quirk, 2005). The lack of significant regulation in the central amygdala is also sur-
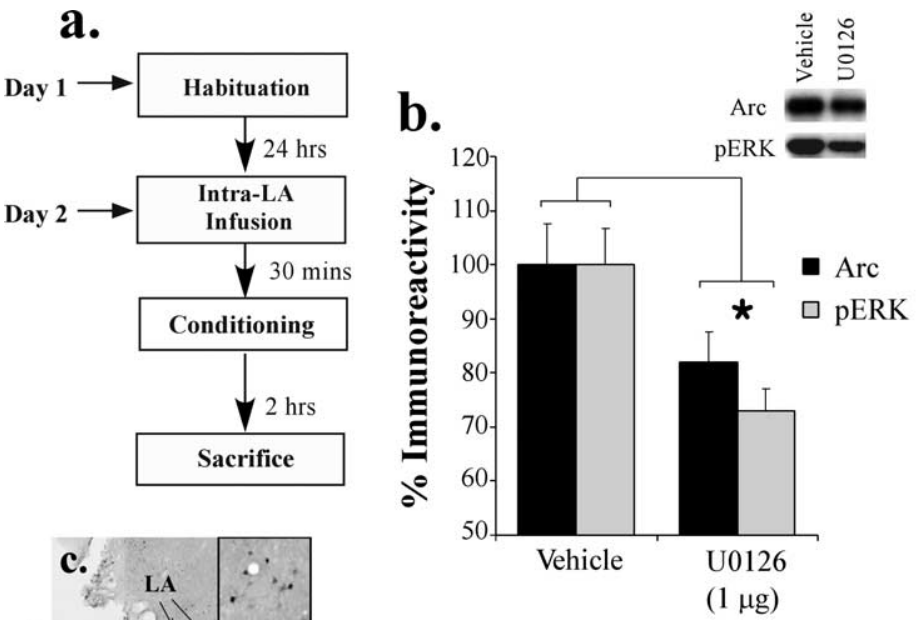

Figure 6. Training-induced expression of Arc/Arg3.1 is impaired by intra-LA infusion of a MEK inhibitor. $\boldsymbol{a}$, Schematic of the behavioral protocol. Rats were given intra-LA infusion of either $50 \%$ DMSO vehicle $(0.5 \mu l ; n=10)$ or the MEK inhibitor U0126 (1 政 列 . e, Quantification of $\operatorname{Arc} / \operatorname{Arg} 3.1$ labeled cells in the LA of Vehicle $(n=4)$ and U0126-treated rats $(n=4) .{ }^{*} p<0.05$ relative to the Vehicle group. $f$, Histological verification of cannula placements for rats infused with vehicle (black circles) or U0126 (white circles). Panels were adapted from Paxinos and Watson (1997).

prising in light of recent findings that have implicated the $\mathrm{CE}$ as a critical locus of fear memory formation and consolidation (Wilensky et al., 2006). Recent theories, however, have suggested that plasticity in the LA may enable plasticity in the CE (Paré et al., 2004), suggesting that plasticity in the CE may be characterized by a different time course than that in the LA. Accordingly, we might expect training-induced IEG regulation in the CE to occur at a later time point than that assayed in the present study. Additional experiments will be necessary to further examine the role of Arc/Arg3.1 in fear memory formation in each of these amygdala subnuclei.

Although a number of studies have examined the role of Arcl Arg3.1 in learning and memory processes, few have explicitly and systemically examined its role in different phases of memory for- 
mation. In our experiments, we show that antisense knockdown of Arc/Arg3.1 in the LA impairs LTM at 24 after fear conditioning, but leaves fear acquisition and STM intact (e.g., at $3 \mathrm{~h}$ after fear learning). These findings are consistent with those of Guzowski et al., 2000, who showed that hippocampal knockdown of Arc/Arg3.1 impairs LTM in the Morris water maze, without affecting acquisition or STM (Guzowski et al., 2000). They are also consistent with those of Plath et al., 2006, who showed that Arc/Arg3.1 knock-out mice have intact acquisition and retention over the first several blocks of trials in the Morris water maze, but begin to show impairments during later trials (Plath et al., 2006). Although this latter finding at first may seem at odds with that of Guzowski et al., 2000, it should be noted that Plath et al., 2006 used a much longer training protocol ( 9 trials), in which each block of trials was separated by $30 \mathrm{~min}$, whereas Guzowski and colleagues used a protocol consisting of only two blocks of trials separated by 30 min (Guzowski et al., 2000; Plath et al., 2006). Together with our own findings, these findings suggest that learning induced transcription and translation of Arc/Arg3.1 promotes long-term synaptic plasticity and memory formation, without affecting short-term plasticity in both hippocampus and amygdala.

The precise mechanism by which Arc/Arg.3.1 contributes to long-term synaptic plasticity and memory formation is currently unknown. Arc/Arg3.1 is known to be induced by patterns of neural activity that promote synaptic plasticity and is thought to be trafficked and localized to recently potentiated synapses (Steward et al., 1998; Steward and Worley, 2001a). In the dentate gyrus, such trafficking and localization of Arc/Arg3.1 mRNA and protein have been readily observed after LTP-inducing synaptic stimulation, a process that requires activation of the NMDA receptor (Steward and Worley, 2001a,b). More recent studies using ultrastructural methods have confirmed that LTP-inducing stimulation is associated with enhanced Arc/Arg3.1 protein expression in dendrites and spines (Rodríguez et al., 2005), and in an input specific manner (Moga et al., 2004). One recent and intriguing hypothesis is that Arc/Arg3.1 regulates AMPA receptor tracking at synapses (Chowdhury et al., 2006; Rial Verde et al., 2006; Shepherd et al., 2006), where expression of Arc/Arg3.1 may regulate synaptic homeostasis (Rial Verde et al., 2006). AMPA receptor regulation is known to be critical for synaptic plasticity and memory formation (Malinow, 2003), including that of fear conditioning (Rumpel et al., 2005). It would be of interest to examine whether fear conditioning or synaptic plasticity in the LA is similarly accompanied by synaptic localization and translation of Arc/Arg3.1 mRNA, an experiment that is beyond the scope of the present manuscript.

In our immunohistochemical experiments, we observed training-induced increases in Arc/Arg3.1 protein in dendritic processes, somas, and nuclei of LA cells. Although trafficking and localization of Arc/Arg3.1 to dendritic and synaptic sites has received much attention, relatively little is known about the functional significance of trafficking of Arc/Arg3.1 protein to the nucleus. This same pattern of regulation, however, has been observed in hippocampus after LTP-inducing stimulation (Steward and Worley, 2001a,b). It has been suggested that Arc/Arg3.1 might play a dual role in long-term synaptic plasticity and memory: one at synapses where it serves to promote synapse-specific plasticity, and another in the nucleus where it may serve to regulate certain aspects of transcription (Bloomer et al., 2007). Although Arc/Arg3.1 is not considered a classical transcription factor like other IEGs (Guzowski, 2002), it may nonetheless regulate transcriptional activity by influencing events in the nuclear ma- trix (Bloomer et al., 2007). Additional experiments will be required to more fully explore the role of Arc/Arg3.1 in the nucleus.

Our behavioral experiments used antisense ODN technology to manipulate Arc/Arg3.1 protein expression in vivo, which presents a number of potential difficulties related to distribution and uptake, efficacy, and toxicity. Although the use of ODNs has proven successful in the hippocampus (Guzowski and McGaugh, 1997; Guzowski et al., 2000; Taubenfeld et al., 2001), fewer studies have used ODNs to manipulate gene expression in the amygdala (but see Malkani et al., 2004; Milekic et al., 2007). In our experiments, we show that intra-LA infusion of a biotinylated Arc/Arg3.1 ODN exhibits significant spread within the LA. The distribution of the ODN both throughout the LA and within cells is prominent at $3 \mathrm{~h}$ after infusion, but is less prominent in the tissue $6 \mathrm{~h}$ later (data not shown). Although we cannot be certain that the nonbiotinylated ODNs used in the behavioral experiments exhibit similar diffusion dynamics, we were able to show that this same volume and dose of ODN given $6 \mathrm{~h}$, but not 3 or $24 \mathrm{~h}$, before brain removal reduces the expression of Arc/Arg3.1 protein by $\sim 20 \%$ in amygdala homogenates relative to controls infused with scrambled ODN. Thus, the ODN appears to require a window of $\sim 6 \mathrm{~h}$ after infusion to begin to result in significant reduction in Arc/Arg3.1 protein expression. The fact that fear acquisition and STM formation is left intact after Arc/Arg3.1 ODN manipulations also rules out possible nonspecific explanations of the ODN effect, including the possibility that Arc/Arg3.1 ODN infusion disrupts fear acquisition by impairing sensory and/or performance factors, including the ability of the amygdala to process tone and shock information. Further, we show that rats treated with the antisense ODN are capable of relearning fear when retrained ODN-free $\sim 1$ week later, suggesting that that antisense ODN treatment, at the doses used in the present study, do not produce a lesion or result in any long-term toxicity to the amygdala. Collectively, these findings provide strong evidence of the usefulness of ODN technologies for manipulating gene expression and memory in the fear learning system.

The results of the present study clearly suggest that Arc/Arg3.1 underlies synaptic plasticity and fear memory consolidation in the LA. These findings expand nicely on those of previous studies that have examined the role of Arc/Arg3.1 in hippocampaldependent learning and memory and make an additional contribution toward understanding the cellular and molecular processes underlying emotional memory formation in the amygdala.

\section{References}

Amorapanth P, LeDoux JE, Nader K (2000) Different lateral amygdala outputs mediate reactions and actions elicited by a fear-arousing stimulus. Nat Neurosci 3:74-79.

Anglada-Figueroa D, Quirk GJ (2005) Lesions of the basal amygdala block expression of conditioned fear but not extinction. J Neurosci 25:9680-9685.

Atkins CM, Selcher JC, Petraitis JJ, Trzaskos JM, Sweatt JD (1998) The MAPK cascade is required for mammalian associative learning. Nat Neurosci 1:602-609.

Bauer EP, Schafe GE, LeDoux JE (2002) NMDA receptors and L-type voltage-gated calcium channels contribute to long-term potentiation and different components of fear memory formation in the lateral amygdala. J Neurosci 22:5239-5249.

Beck CH, Fibiger HC (1995) Conditioned fear-induced changes in behavior and in the expression of the immediate early gene c-fos: with and without diazepam pretreatment. J Neurosci 15:709-720.

Blair HT, Schafe GE, Bauer EP, Rodrigues SM, LeDoux JE (2001) Synaptic plasticity in the lateral amygdala: A cellular hypothesis of fear conditioning. Learn Mem 8:229-242.

Bloomer WA, VanDongen HM, VanDongen AM (2007) Activity-regulated cytoskeleton-associated protein Arc/Arg3.1 binds to spectrin and associ- 
ates with nuclear promyelocytic leukemia (PML) bodies. Brain Res 1153:20-33.

Blum S, Moore AN, Adams F, Dash PK (1999) A mitogen-activated protein kinase cascade in the CA1/CA2 subfield of the dorsal hippocampus is essential for long-term spatial memory. J Neurosci 19:3535-3544.

Brambilla R, Gnesutta N, Minichiello L, White G, Roylance AJ, Herron CE, Ramsey M, Wolfer DP, Cestari V, Rossi-Arnaud C, Grant SG, Chapman PF, Lipp HP, Sturani E, Klein R (1997) A role for the Ras signaling pathway in synaptic transmission and long-term memory. Nature 390:281-286.

Chowdhury S, Shepherd JD, Okuno H, Lyford G, Petralia RS, Plath N, Kuhl D, Huganir RL, Worley PF (2006) Arc/Arg3.1 interacts with the endocytic machinery to regulate AMPA receptor trafficking. Neuron 52:445-459.

Davis S, Vanhoutte P, Pages C, Caboche J, Laroche S (2000) The MAPK/ ERK cascade targets both Elk-1 and cAMP response element- binding protein to control long-term potentiation-dependent gene expression in the dentate gyrus in vivo. J Neurosci 20:4563-4572.

Doyère V, Schafe GE, Sigurdsson T, LeDoux JE (2003) Long-term potentiation in freely moving rats reveals asymmetries in thalamic and cortical inputs to the lateral amygdala. Eur J Neurosci 17:2703-2715.

English JD, Sweatt JD (1996) Activation of p42 mitogen-activated protein kinase in hippocampal long term potentiation. J Biol Chem 271:24329-24332.

English JD, Sweatt JD (1997) A requirement for the mitogen-activated protein kinase cascade in hippocampal long term potentiation. J Biol Chem 272:19103-19106.

Fanselow MS (1980) Conditioned and unconditional components of postshock freezing. Pavlov J Biol Sci 15:177-182.

Favata MF, Horiuchi KY, Manos EJ, Daulerio AJ, Stradley DA, Feeser WS, Van Dyk DE, Pitts WJ, Earl RA, Hobbs F, Copeland RA, Magolda RL, Scherle PA, Trzaskos JM (1998) Identification of a novel inhibitor of mitogen-activated protein kinase kinase. J Biol Chem 273:18623-18632.

Goosens KA, Maren S (2001) Contextual and auditory fear conditioning are mediated by the lateral, basal, and central amygdaloid nuclei in rats. Learn Mem 8:148-155

Goosens KA, Maren S (2004) NMDA receptors are essential for the acquisition, but not expression, of conditional fear and associative spike firing in the lateral amygdala. Eur J Neurosci 20:537-548.

Guzowski JF (2002) Insights into immediate-early gene function in hippocampal memory consolidation using antisense oligonucleotide and fluorescent imaging approaches. Hippocampus 12:86-104.

Guzowski JF, McGaugh JL (1997) Antisense oligodeoxynucleotidemediated disruption of hippocampal cAMP response element binding protein levels impairs consolidation of memory for water maze training. Proc Natl Acad Sci U S A 94:2693-2698.

Guzowski JF, Lyford GL, Stevenson GD, Houston FP, McGaugh JL, Worley PF, Barnes CA (2000) Inhibition of activity-dependent arc protein expression in the rat hippocampus impairs the maintenance of long-term potentiation and the consolidation of long-term memory. J Neurosci 20:3993-4001.

Hall J, Thomas KL, Everitt BJ (2001a) Cellular imaging of zif268 expression in the hippocampus and amygdala during contextual and cued fear memory retrieval: selective activation of hippocampal CA1 neurons during the recall of contextual memories. J Neurosci 21:2186-2193.

Hall J, Thomas KL, Everitt BJ (2001b) Fear memory retrieval induces CREB phosphorylation and Fos expression within the amygdala. Eur J Neurosci 13:1453-1458.

Huang F, Chotiner JK, Steward O (2007) Actin polymerization and ERK phosphorylation are required for Arc/Arg3.1 mRNA targeting to activated synaptic sites on dendrites. J Neurosci 27:9054-9067.

Huff NC, Frank M, Wright-Hardesty K, Sprunger D, Matus-Amat P, Higgins E, Rudy JW (2006) Amygdala regulation of immediate-early gene expression in the hippocampus induced by contextual fear conditioning. J Neurosci 26:1616-1623.

Impey S, Obrietan K, Wong ST, Poser S, Yano S, Wayman G, Deloulme JC, Chan G, Storm DR (1998) Cross talk between ERK and PKA is required for $\mathrm{Ca} 2+$ stimulation of CREB-dependent transcription and ERK nuclear translocation. Neuron 21:869-883.

Impey S, Obrietan K, Storm DR (1999) Making new connections: role of ERK/MAP kinase signaling in neuronal plasticity. Neuron 23:11-14.

Josselyn SA, Shi C, Carlezon WA Jr, Neve RL, Nestler EJ, Davis M (2001)
Long-term memory is facilitated by cAMP response element-binding protein overexpression in the amygdala. J Neurosci 21:2404-2412.

LeDoux JE (2000) Emotion circuits in the brain. Annu Rev Neurosci 23:155-184.

LeDoux JE, Cicchetti P, Xagoraris A, Romanski LM (1990) The lateral amygdaloid nucleus: sensory interface of the amygdala in fear conditioning. J Neurosci 10:1062-1069.

Lin CH, Yeh SH, Lin CH, Lu KT, Leu TH, Chang WC, Gean PW (2001) A role for the PI-3 kinase signaling pathway in fear conditioning and synaptic plasticity in the amygdala. Neuron 31:841-851.

Lyford GL, Yamagata K, Kaufmann WE, Barnes CA, Sanders LK, Copeland NG, Gilbert DJ, Jenkins NA, Lanahan AA, Worley PF (1995) Arc, a growth factor and activity-regulated gene, encodes a novel cytoskeletonassociated protein that is enriched in neuronal dendrites. Neuron 14:433-445.

Malinow R (2003) AMPA receptor trafficking and long-term potentiation. Philos Trans R Soc Lond B Biol Sci 358:707-714.

Malkani S, Rosen JB (2000a) Specific induction of early growth response gene 1 in the lateral nucleus of the amygdala following contextual fear conditioning in rats. Neuroscience 97:693-702.

Malkani S, Rosen JB (2000b) Induction of NGFI-B mRNA following contextual fear conditioning and its blockade by diazepam [In Process Citation]. Brain Res Mol Brain Res 80:153-165.

Malkani S, Wallace KJ, Donley MP, Rosen JB (2004) An egr-1 (zif268) antisense oligodeoxynucleotide infused into the amygdala disrupts fear conditioning. Learn Mem 11:617-624.

Maren S (2001) Neurobiology of pavlovian fear conditioning. Annu Rev Neurosci 24:897-931.

Maren S, Fanselow MS (1995) Synaptic plasticity in the basolateral amygdala induced by hippocampal formation stimulation in vivo. J Neurosci 15:7548-7564.

Milekic MH, Pollonini G, Alberini CM (2007) Temporal requirement of $\mathrm{C} / \mathrm{EBPbeta}$ in the amygdala following reactivation but not acquisition of inhibitory avoidance. Learn Mem 14:504-511.

Miserendino MJ, Sananes CB, Melia KR, Davis M (1990) Blocking of acquisition but not expression of conditioned fear-potentiated startle by NMDA antagonists in the amygdala. Nature 345:716-718.

Moga DE, Calhoun ME, Chowdhury A, Worley P, Morrison JH, Shapiro ML (2004) Activity-regulated cytoskeletal-associated protein is localized to recently activated excitatory synapses. Neuroscience 125:7-11.

Montag-Sallaz M, Montag D (2003) Learning-induced arg 3.1/arc mRNA expression in the mouse brain. Learn Mem 10:99-107.

Nader K, Majidishad P, Amorapanth P, LeDoux JE (2001) Damage to the lateral and central, but not other, amygdaloid nuclei prevents the acquisition of auditory fear conditioning. Learn Mem 8:156-163.

Newton SS, Collier EF, Hunsberger J, Adams D, Terwilliger R, Selvanayagam E, Duman RS (2003) Gene profile of electroconvulsive seizures: induction of neurotrophic and angiogenic factors. J Neurosci 23:10841-10851.

Paré, D, Quirk GJ, LeDoux JE (2004) New vistas on amygdala networks in conditioned fear. J Neurophysiol 92:1-9.

Paxinos G, Watson C (1997) The rat brain in stereotaxic coordinates. San Diego: Academic

Plath N, Ohana O, Dammermann B, Errington ML, Schmitz D, Gross C, Mao X, Engelsberg A, Mahlke C, Welzl H, Kobalz U, Stawrakakis A, Fernandez E, Waltereit R, Bick-Sander A, Therstappen E, Cooke SF, Blanquet V, Wurst W, Salmen B, Bösl MR, Lipp HP, Grant SG, Bliss TV, Wolfer DP, Kuhl D (2006) Arc/Arg3.1 is essential for the consolidation of synaptic plasticity and memories. Neuron 52:437-444.

Ploski JE, Newton SS, Duman RS (2006) Electroconvulsive seizure-induced gene expression profile of the hippocampus dentate gyrus granule cell layer. J Neurochem 99:1122-1132.

Quirk GJ, Repa C, LeDoux JE (1995) Fear conditioning enhances shortlatency auditory responses of lateral amygdala neurons: parallel recordings in the freely behaving rat. Neuron 15:1029-1039.

Radulovic J, Kammermeier J, Spiess J (1998) Relationship between fos production and classical fear conditioning: effects of novelty, latent inhibition, and unconditioned stimulus preexposure. J Neurosci 18:7452-7461.

Radwanska K, Nikolaev E, Knapska E, Kaczmarek L (2002) Differential response of two subdivisions of lateral amygdala to aversive conditioning as revealed by c-Fos and P-ERK mapping. Neuroreport 13:2241-2246.

Rattiner LM, Davis M, French CT, Ressler KJ (2004) Brain-derived neuro- 
trophic factor and tyrosine kinase receptor B involvement in amygdaladependent fear conditioning. J Neurosci 24:4796-4806.

Ressler KJ, Paschall G, Zhou XL, Davis M (2002) Regulation of synaptic plasticity genes during consolidation of fear conditioning. J Neurosci 22:7892-7902.

Rial Verde EM, Lee-Osbourne J, Worley PF, Malinow R, Cline HT (2006) Increased expression of the immediate-early gene arc/arg3.1 reduces AMPA receptor-mediated synaptic transmission. Neuron 52:461-474.

Roberson ED, English JD, Adams JP, Selcher JC, Kondratick C, Sweatt JD (1999) The mitogen-activated protein kinase cascade couples PKA and $\mathrm{PKC}$ to cAMP response element binding protein phosphorylation in area CA1 of hippocampus. J Neurosci 19:4337-4348.

Rodrigues SM, Schafe GE, LeDoux JE (2001) Intraamygdala blockade of the NR2B subunit of the NMDA receptor disrupts the acquisition but not the expression of fear conditioning. J Neurosci 21:6889-6896.

Rodrigues SM, Bauer EP, Farb CR, Schafe GE, LeDoux JE (2002) The group I metabotropic glutamate receptor mGluR5 is required for fear memory formation and long-term potentiation in the lateral amygdala. J Neurosci 22:5219-5229.

Rodrigues SM, Schafe GE, LeDoux JE (2004a) Molecular mechanisms underlying emotional learning and memory in the lateral amygdala. Neuron 44:75-91.

Rodrigues SM, Farb CR, Bauer EP, LeDoux JE, Schafe GE (2004b) Pavlovian fear conditioning regulates Thr286 autophosphorylation of $\mathrm{Ca} 2+/$ calmodulin-dependent protein kinase II at lateral amygdala synapses. J Neurosci 24:3281-3288.

Rodríguez JJ, Davis HA, Silva AT, DeSouza IE, Peddie CJ, Colyer FM, Lancashire CL, Fine A, Errington ML, Bliss TV, Stewart MG (2005) Longterm potentiation in the rat dentate gyrus is associated with enhanced Arc/Arg3.1 protein expression in spines, dendrites and glia. Eur J Neurosci 21:2384-2396.

Rogan MT, Stäubli UV, LeDoux JE (1997) Fear conditioning induces associative long-term potentiation in the amygdala. Nature 390:604-607.

Rosen JB, Fanselow MS, Young SL, Sitcoske M, Maren S (1998) Immediateearly gene expression in the amygdala following footshock stress and contextual fear conditioning. Brain Res 796:132-142.

Rumpel S, LeDoux J, Zador A, Malinow R (2005) Postsynaptic receptor trafficking underlying a form of associative learning. Science 308:83-88.

Schafe GE, LeDoux JE (2000) Memory consolidation of auditory pavlovian fear conditioning requires protein synthesis and protein kinase $\mathrm{A}$ in the amygdala. J Neurosci 20:RC96.

Schafe GE, Nadel NV, Sullivan GM, Harris A, LeDoux JE (1999) Memory consolidation for contextual and auditory fear conditioning is dependent on protein synthesis, PKA, and MAP kinase. Learn Mem 6:97-110.

Schafe GE, Atkins CM, Swank MW, Bauer EP, Sweatt JD, LeDoux JE (2000) Activation of ERK/MAP kinase in the amygdala is required for memory consolidation of pavlovian fear conditioning. J Neurosci 20:8177-8187.

Schafe GE, Nader K, Blair HT, LeDoux JE (2001) Memory consolidation of pavlovian fear conditioning: a cellular and molecular perspective. Trends Neurosci 24:540-546.

Schafe GE, Doyère V, LeDoux JE (2005) Tracking the fear engram: the lat- eral amygdala is an essential locus of fear memory storage. J Neurosci 25:10010-10014.

Schafe GE, Swank MW, Rodrigues SM, Debiec J, Doyère V (2008) Phosphorylation of ERK/MAP kinase is required for long-term potentiation in anatomically restricted regions of the lateral amygdala in vivo. Learn Mem 15:55-62.

Scicli AP, Petrovich GD, Swanson LW, Thompson RF (2004) Contextual fear conditioning is associated with lateralized expression of the immediate early gene $\mathrm{c}$-fos in the central and basolateral amygdalar nuclei. Behav Neurosci 118:5-14.

Shepherd JD, Rumbaugh G, Wu J, Chowdhury S, Plath N, Kuhl D, Huganir RL, Worley PF (2006) Arc/Arg3.1 mediates homeostatic synaptic scaling of AMPA receptors. Neuron 52:475-484.

Steward O, Worley PF (2001a) A cellular mechanism for targeting newly synthesized mRNAs to synaptic sites on dendrites. Proc Natl Acad Sci U S A 98:7062-7068.

Steward O, Worley PF (2001b) Selective targeting of newly synthesized Arc mRNA to active synapses requires NMDA receptor activation. Neuron 30:227-240.

Steward O, Worley P (2002) Local synthesis of proteins at synaptic sites on dendrites: role in synaptic plasticity and memory consolidation? Neurobiol Learn Mem 78:508-527.

Steward O, Wallace CS, Lyford GL, Worley PF (1998) Synaptic activation causes the mRNA for the IEG Arc to localize selectively near activated postsynaptic sites on dendrites. Neuron 21:741-751.

Strekalova T, Zörner B, Zacher C, Sadovska G, Herdegen T, Gass P (2003) Memory retrieval after contextual fear conditioning induces c-Fos and JunB expression in CA1 hippocampus. Genes Brain Behav 2:3-10.

Sweatt JD (2004) Mitogen-activated protein kinases in synaptic plasticity and memory. Curr Opin Neurobiol 14:311-317.

Taubenfeld SM, Milekic MH, Monti B, Alberini CM (2001) The consolidation of new but not reactivated memory requires hippocampal C/EBPbeta. Nat Neurosci 4:813-818.

von Hertzen LS, Giese KP (2005) Memory reconsolidation engages only a subset of immediate-early genes induced during consolidation. J Neurosci 25:1935-1942.

Waltereit R, Dammermann B, Wulff P, Scafidi J, Staubli U, Kauselmann G, Bundman M, Kuhl D (2001) Arg3.1/Arc mRNA induction by Ca2+ and cAMP requires protein kinase $\mathrm{A}$ and mitogen-activated protein kinase/ extracellular regulated kinase activation. J Neurosci 21:5484-5493.

Wilensky AE, Schafe GE, Kristensen MP, LeDoux JE (2006) Rethinking the fear circuit: the central nucleus of the amygdala is required for the acquisition, consolidation, and expression of pavlovian fear conditioning. J Neurosci 26:12387-12396.

Yaniv D, Schafe GE, LeDoux JE, Richter-Levin G (2000) Perirhinal cortex and thalamic stimulation induces LTP in different areas of the amygdala. Ann N Y Acad Sci 911:474-476.

Yaniv D, Schafe GE, LeDoux JE, Richter-Levin G (2001) A gradient of plasticity in the amygdala revealed by cortical and subcortical stimulation, in vivo. Neuroscience 106:613-620. 